\title{
Czech Republic: Financial System Stability Assessment Update
}

This paper was prepared based on the information available at the time it was completed in April 2012. The views expressed in this document are those of the staff team and do not necessarily reflect the views of the government of Czech Republic or the Executive Board of the IMF.

The policy of publication of staff reports and other documents by the IMF allows for the deletion of market-sensitive information.

Copies of this report are available to the public from

International Monetary Fund • Publication Services

700 19th Street, N.W. • Washington, D.C. 20431

Telephone: (202) 623-7430 • Telefax: (202) 623-7201

E-mail: publications@imf.org • Internet: http://www.imf.org

\section{International Monetary Fund Washington, D.C.}




\title{
INTERNATIONAL MONETARY FUND
}

\section{CZECH REPUBLIC}

\section{Financial System Stability Assessment Update}

\author{
Prepared by the Monetary and Capital Markets and European Departments
}

Approved by José Viñals and Reza Moghadam

April 4, 2012

This report summarizes the findings of the IMF Financial Sector Assessment Program (FSAP) Update mission, which visited the Czech Republic in November/December 2011. The FSAP findings and recommendations were discussed with the Czech authorities during the Article IV consultation mission in February 2012.

The FSAP team comprised Maher Hasan (head), Su Hoong Chang, Piyabha Kongsamut, Vassili Prokopenko, Christian Schmieder, Constant Verkoren (all MCM), Engin Dalgic (EUR), Dinah Knight (LEG), and Goran Lind (external expert). Key findings of the FSAP Update:

- $\quad$ Strong economic fundamentals helped Czech financial institutions to withstand the effects of the global financial crisis relatively unscathed. Banks have ample capital and liquidity, and solid profitability.

- $\quad$ Stress test results show that Czech banks are resilient against substantial shocks. Only the vulnerability to a severe double dip scenario with a simultaneous contagion from parent banks is substantial, but the likelihood of such a risk materializing is considered low at present.

- $\quad$ The financial stability mandate of the CNB should be clarified. The regulatory and supervisory framework for financial institutions is generally sound but suffers from inadequate resources. The crisis management and resolution framework is broadly appropriate but has several weaknesses, including related to the deposit guarantee scheme.

The main authors of this report are Piyabha Kongsamut and Vassili Prokopenko, with contributions from the rest of the FSAP team.

FSAP assessments are designed to assess the stability of the financial system as a whole and not that of individual institutions. They have been developed to help countries identify and remedy weaknesses in their financial sector structure, thereby enhancing their resilience to macroeconomic shocks and cross-border contagion. FSAP assessments do not cover risks that are specific to individual institutions such as asset quality, operational or legal risks, or fraud. 
Glossary

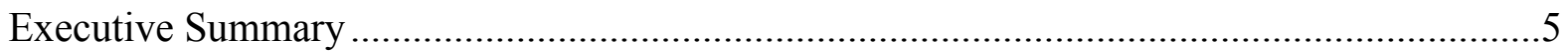

I. Macroeconomic Setting and Structure of the Financial System............................................

A. Macroeconomic Setting ……………..............................................................

B. Structure of the Financial System …………………...........................................

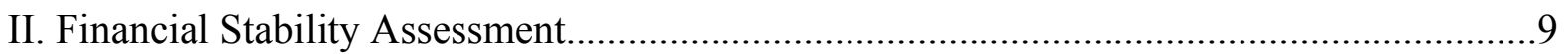

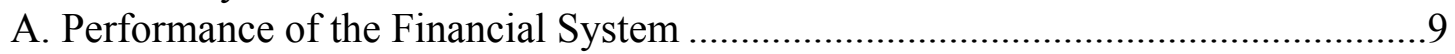

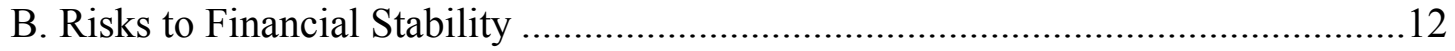

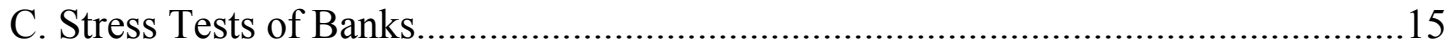

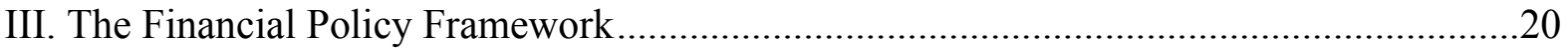

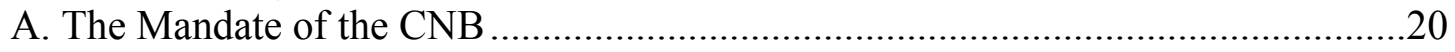

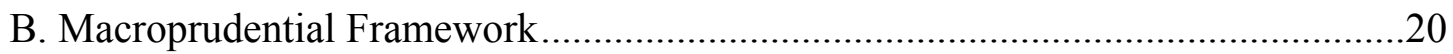

C. Regulation and Supervision ............................................................................21

D. Crisis Management and Resolution ....................................................................22

Tables

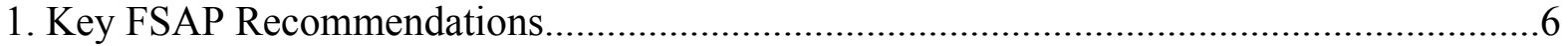

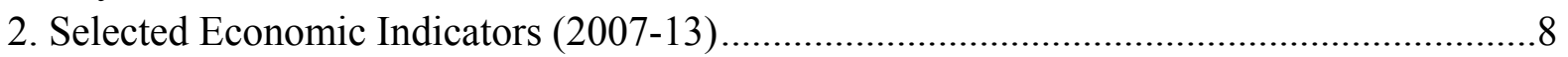

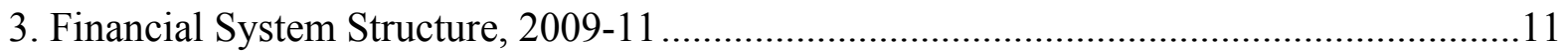

4. Financial Soundness Indicators of the Banking Sector, 2008-2010..................................13

5. Summary Compliance with the Basel Core Principles-ROSCs .........................................37

6. Recommended Action Plan to Improve Compliance with the Basel Core Principles..........41

Figures

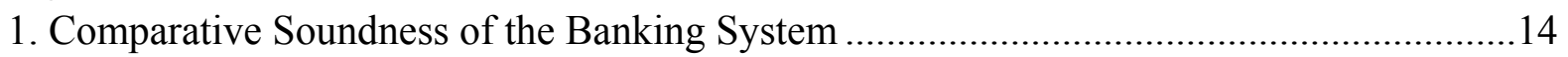

2. GDP Trajectories Under Different Stress Test Scenarios.................................................17

3. Outcome of Solvency Stress Tests for the Czech Banking System....................................19

4. Outcome of Liquidity Stress Tests for the Czech Banking System.....................................19

\section{Appendixes}

I. 2002 FSAP Main Recommendations: Status of Implementation ........................................25

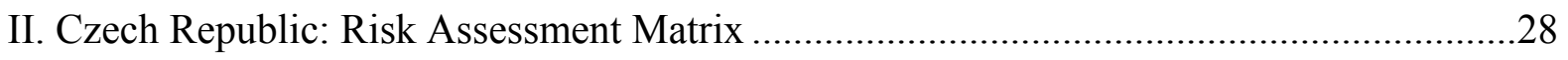

III: Stress Test Matrix: Solvency and Liquidity Risks.........................................................30 
Annex I. Summary Observance of the Basel Core Principles for Effective Banking

Supervision 32

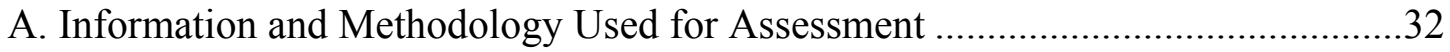

B. Institutional and Macroeconomic Setting and Market Structure-Overview..........32

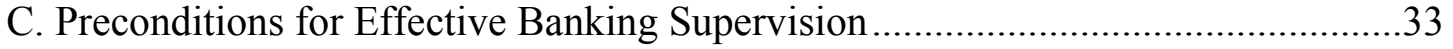

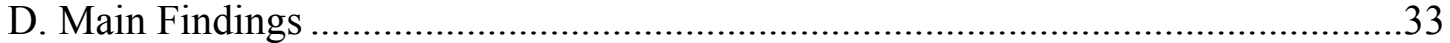




\section{GLOSSARY}

$\begin{array}{ll}\text { AML/CFT } & \text { Anti-Money Laundering/Combating the Financing of Terrorism } \\ \text { BCP } & \text { Basel Core Principles } \\ \text { BU } & \text { Bottom up } \\ \text { CEE } & \text { Central and Eastern European } \\ \text { CMG } & \text { Crisis management group } \\ \text { CNB } & \text { Czech National Bank } \\ \text { CSC } & \text { Czech Securities Commission } \\ \text { CP } & \text { Core Principle } \\ \text { CU } & \text { Credit Union } \\ \text { DD } & \text { Double dip } \\ \text { DIF } & \text { Deposit Insurance Fund } \\ \text { EBA } & \text { European Banking Authority } \\ \text { ECB } & \text { European Central Bank } \\ \text { EU } & \text { European Union } \\ \text { FATF } & \text { Financial Action Task Force } \\ \text { FSAP } & \text { Financial Sector Assessment Program } \\ \text { IFRS } & \text { International Financial Reporting Standards } \\ \text { IRB } & \text { Internal ratings-based } \\ \text { MOF } & \text { Ministry of finance } \\ \text { MOU } & \text { Memorandum of Understanding } \\ \text { NBFI } & \text { Nonbank financial institution } \\ \text { NPL } & \text { Nonperforming loan } \\ \text { PEP } & \text { Politically exposed person } \\ \text { TD } & \text { Top down } \\ & \end{array}$




\section{EXECUTIVE SUMMARY}

Sound fundamentals of the Czech economy prior to the global crisis contained the buildup of systemic financial vulnerabilities. Strong external and fiscal positions and the credibility of monetary and exchange rate policies contributed to the resilience of economy and the financial system. The capitalization of banks has actually improved since 2008, reflecting slowed credit growth and strong profits, and bank liquidity is ample as evidenced by relatively low loan-to-deposit ratios.

Nevertheless, the financial system is confronted with a number of growing risks. Due to a high reliance of the Czech economy on exports to European Union (EU) countries and the ownership of almost all large Czech financial institutions by parents from the EU, the main risk stems from negative developments in EU countries. The Czech financial system could be affected either directly through the parent banks, or indirectly through weakened external demand, and the two channels may occur simultaneously. From the domestic perspective, the real estate market could amplify the impact of the above risks.

The results of stress tests show that Czech banks can withstand substantial shocks. The majority of banks would remain adequately capitalized even in the event of a large deterioration in the quality of assets under a severe double dip (DD) scenario. Only in the event of a scenario combining a severe DD and a partial loss on exposures to foreign parent banks would the system-wide capital adequacy ratio fall below the prudential minimum of 8 percent. The vast majority of Czech banks can cope with large liquidity shocks.

The legal setting for the Czech National Bank's (CNB) financial stability mandate should be strengthened. According to the current law, the CNB's objective is to ensure price stability, while financial stability is one of the supporting elements of achieving the price stability. The CNB's functions for financial stability include micro and macroprudential supervision as well as crisis management and bank resolution. Elevating the financial stability mandate beyond a supporting element will establish a stronger accountability framework for all of these functions.

The regulatory and supervisory framework for financial institutions is generally sound, although inadequate resources are a major weakness. Limited resources result in infrequent on-site inspections of banks, including supervision of Anti-Money Laundering/Combating the Financing of Terrorism (AML/CFT) obligations, insufficient contacts between the supervisor and banks, delays in taking administrative action, etc. Moreover, the CNB should introduce a structured framework for early intervention, based on quantitative as well as judgmental criteria, to strengthen accountability and compliance. The supervision of financial conglomerates should be strengthened to allow effective and timely identification of potential problems. The small but rapidly growing credit union sector requires a major overhaul. 
The crisis management and resolution framework is broadly appropriate but has several gaps. The threshold for appointment of a conservator should be changed to be more flexible. The governance structure of the deposit insurance fund (DIF, deposit guarantee scheme in Czech Republic) should be improved by limiting the participation of active industry representatives on the board, its size should be increased to limit the risk to public resources, and the trigger for payout should be clarified with a view to reducing uncertainties for depositors. The framework for using public funds to provide exceptional support to privately-owned banks should be further operationalized.

The key recommendations of the mission are presented in Table 1. Appendix I shows the status of recommendations made by the 2001 FSAP.

\section{Table 1. Key FSAP Recommendations}

\section{CNB's Mandate}

Elevate financial stability to a policy objective in the CNB law (ף 17)

Medium Medium term

\section{Macroprudential framework}

Improve the decision-making mechanisms within the CNB to take timely action to address systemic risk ( $\mathbb{( 1 8 )}$

Upgrade the stress testing framework for banks, focusing on group-wide risk monitoring (đ 19)

\section{Regulation and supervision}

Increase the number of supervisory staff to strengthen the intrusiveness of supervision ( $\mathbb{T} 21)$

Introduce a "prompt corrective action" framework (\$ 22)

Set large exposure limits in line with the globally agreed levels ( $(\mathbb{1} 23)$

Continue closely monitoring significant transactions between subsidiaries and their parents, and take action, if necessary ( $\mathbb{T} 24)$

Strengthen the framework for supervising financial conglomerate ( $\mathbb{( \pi} 25)$

Strengthen the CU sector by restructuring the existing institutions ( $(\mathbb{2} 26)$

High Near term

Medium Near term

\section{Crisis management and resolution frameworks}

Operationalize the framework for providing public support to banks (T 28)

Adjust the threshold for imposing conservatorship (\$ 29)

Enhance governance of the DIF, increase the target of the DIF and strengthen the provisions for budgetary financing of possible shortfalls, clarify the trigger for payout of insured deposits, and allow the DIF to fund the transfer of deposits via purchase \& assumption agreements ( $\$ 30$ )

$\begin{array}{cc}\text { High } & \text { Immediate } \\ \text { Medium } & \text { Near term } \\ \text { High } & \text { Near term } \\ \text { High } & \text { Ongoing } \\ \text { High } & \text { Near Term } \\ \text { Medium } & \text { Near Term } \\ & \\ \text { High } & \text { Near term } \\ \text { High } & \text { Near term } \\ \text { Medium } & \text { Medium term }\end{array}$

Near term: to be completed within one year. Medium term: to be completed within three years. 


\section{Macroeconomic Setting ANd Structure of the Financial System}

\section{A. Macroeconomic Setting}

\section{The Czech economy weathered the global financial crisis relatively well} (Table 2). Limited external financing needs, a flexible exchange rate regime, a credible monetary policy framework, healthy public and private balance sheets without currency mismatches, and the absence of major pre-crisis asset bubbles helped contain the negative external shock and limited output decline. Monetary and fiscal easing too helped cushion the economic downturn. Despite the relatively favorable initial conditions and supportive policies, the subsequent recovery has been driven mainly by export growth, particularly to Germany. In contrast, domestic demand has been weak partly due to fiscal consolidation.

2. The post-crisis recovery stalled in the second half of 2011 , and the economy faces substantial headwinds from the euro area recession. Activity is expected to remain flat in 2012 as exports continue to be affected by the Euro Area weakness and domestic demand is likely to be anemic. Risks to this scenario are tilted to the downside. A potential intensification of the sovereign debt crisis in Europe would negatively impact the economy through the trade channel, and the close financial integration with the Euro Area entails a clear spillover risk via financial contagion. So far, contagion has been limited; the risk premiums on Czech assets have increased, but remain well below levels seen in the 2008-09 crisis and compare favorably with regional peers as well as Euro Area countries.

\section{The household and corporate sectors are in a relatively sound position, but} macroeconomic uncertainty weighs on prospects. The Czech nonfinancial corporate sector has a relatively low indebtedness, with financial liabilities at 46 percent of GDP. ${ }^{1}$ During the crisis, the nonperforming loan (NPL) ratio for the corporate sector rose sharply from about 3 percent in 2007 to about 9 percent in 2009, but it has since stabilized and entered a moderate downtrend in 2010-11. 'Households' financial position deteriorated during the period of rapid credit expansion, but gross household debt to GDP, currently at about 35 percent, is still low by international standards. However, domestic demand has remained weak during the recovery, which, coupled with the ongoing slowdown in the Euro Area, have the potential to lead to a renewed bout of credit deterioration in the sector.

\footnotetext{
${ }^{1}$ Several large corporates are parts of regional groups and are financed by the group or by the groups' banking providers.

${ }^{2}$ The highest NPL ratios are reported on loans to the construction, manufacturing, and transport sectors.
} 
Table 2. Selected Economic Indicators (2007-13)

\begin{tabular}{|c|c|c|c|c|c|c|c|}
\hline & 2007 & 2008 & 2009 & 2010 & 2011 & 2012 & 2013 \\
\hline & & & & & Prelim. & \multicolumn{2}{|c|}{ Staff Proj. } \\
\hline Nominal GDP (USD billions) & 180.5 & 225.4 & 196.2 & 197.7 & 215.3 & 206.0 & 213.6 \\
\hline Population (millions) & 10.3 & 10.4 & 10.5 & 10.5 & 10.5 & 10.6 & 10.6 \\
\hline GDP per capita (USD thousands) & 17,544 & 21,715 & 18,739 & 18,814 & 20,444 & 19,515 & 20,196 \\
\hline \multicolumn{8}{|l|}{ Real economy (change in percent, unless stated otherwise) } \\
\hline Real GDP & 5.7 & 3.1 & -4.7 & 2.7 & 1.7 & 0.1 & 2.1 \\
\hline Domestic demand & 6.6 & 2.2 & -5.9 & 2.0 & -1.0 & -1.4 & 1.4 \\
\hline Private consumption & 4.2 & 2.8 & -0.4 & 0.6 & -0.5 & -0.3 & 1.2 \\
\hline Investment & 15.5 & 1.9 & -20.8 & 5.9 & -1.6 & -3.7 & 2.7 \\
\hline Exports & 11.2 & 4.0 & -10.0 & 16.4 & 11.0 & -1.2 & 6.0 \\
\hline Imports & 12.8 & 2.7 & -11.6 & 16.0 & 7.5 & -3.2 & 5.7 \\
\hline Ouput gap (percent of potential output) & 3.1 & 2.8 & -3.6 & -2.5 & -1.9 & -3.5 & -3.2 \\
\hline $\mathrm{CPI}$ (average) & 2.9 & 6.3 & 1.0 & 1.5 & 1.9 & 3.5 & 1.9 \\
\hline PPI (average) & 4.1 & 4.5 & -3.1 & 1.3 & 5.5 & $\ldots$ & $\ldots$ \\
\hline Unemployment rate (in percent) & 5.3 & 4.4 & 6.7 & 7.3 & 6.7 & 7.0 & 7.4 \\
\hline Gross national savings (percent of GDP) & 25.4 & 26.8 & 21.6 & 22.1 & 21.5 & 21.3 & 21.8 \\
\hline Gross domestic investments (percent of GDP) & 29.8 & 28.9 & 24.0 & 25.1 & 24.5 & 23.4 & 23.7 \\
\hline \multicolumn{8}{|l|}{ Public finance (percent of GDP) 1/ } \\
\hline General government revenue & 40.3 & 38.9 & 39.1 & 39.3 & 40.7 & 41.3 & 41.2 \\
\hline General government expenditure & 41.0 & 41.1 & 44.9 & 44.1 & 44.5 & 44.9 & 44.6 \\
\hline Net lending / Overall balance & -0.7 & -2.2 & -5.8 & -4.8 & -3.8 & -3.5 & -3.4 \\
\hline Primary balance & 0.4 & -1.2 & -4.6 & -3.4 & -2.4 & -2.0 & -1.8 \\
\hline Structural balance & -1.8 & -3.2 & -4.5 & -3.9 & -3.1 & -2.3 & -2.2 \\
\hline General government debt & 28.0 & 28.7 & 34.3 & 37.6 & 41.5 & 43.9 & 45.4 \\
\hline \multicolumn{8}{|l|}{ Money and credit (end of year, percent change) } \\
\hline Broad money (M3) & 16.1 & 13.6 & 0.2 & 1.9 & 2.7 & $\ldots$ & $\ldots$ \\
\hline Private sector credit & 26.6 & 16.1 & 0.8 & 3.0 & 5.5 & $\ldots$ & $\ldots$ \\
\hline \multicolumn{8}{|l|}{ Interest rates (in percent, year average) } \\
\hline Three-month interbank rate & 3.1 & 4.0 & 2.2 & 1.3 & 1.2 & $\ldots$ & $\ldots$ \\
\hline Ten-year government bond & 4.3 & 4.6 & 4.7 & 3.7 & 3.5 & $\ldots$ & $\ldots$ \\
\hline \multicolumn{8}{|l|}{ Balance of payments (percent of GDP) } \\
\hline Trade balance (goods and services) & 2.9 & 2.7 & 4.3 & 3.4 & 4.2 & 5.0 & 5.2 \\
\hline Current account balance & -4.4 & -2.1 & -2.5 & -3.0 & -2.9 & -2.1 & -1.9 \\
\hline Gross international reserves (US\$ billion) & 34.9 & 37.0 & 41.6 & 42.5 & 40.3 & 42.9 & 44.9 \\
\hline (in months of imports of goods and services) & 3.5 & 3.2 & 4.5 & 3.9 & 3.2 & 3.8 & 3.9 \\
\hline (in percent of short term debt, remaining maturity) & 113.5 & 100.1 & 131.6 & 132.6 & 122.8 & 133.5 & 135.9 \\
\hline \multicolumn{8}{|l|}{ Exchange rate } \\
\hline Nominal effective exchange rate (index, $2000=100$ ) & 108.1 & 121.6 & 116.3 & 118.7 & 122.4 & n.a. & n.a. \\
\hline Real effective exchange rate (index, CPI-based; $2000=100$ ) & 108.8 & 125.5 & 120.5 & 122.5 & 125.0 & n.a. & n.a. \\
\hline
\end{tabular}

Sources: Czech Statistical Office; Czech National Bank; Ministry of Finance; HAVER, and IMF staff estimates and projections.

1/ Assumes unchanged policies 


\section{Property prices have substantially declined since 2008, reflecting subdued}

demand. Prices in certain residential segments rose by as much as 70 percent between 2004 and 2008 , followed by a fall of about 25 percent. This rate of decline has subsided recently to an annual range of 1-3 percent. While prices continue to decline, the dominance of owner occupiers among the borrowers, prudent loan-to-value ratios, and the low interest rates have limited the credit risks stemming from the mortgage loans for the financial system, and the NPLs for this category have risen to a peak of about 3 percent. Nevertheless, loans to the real estate sector pose a significant risk, as their weight in the overall portfolio rose significantly during the boom period, and unsold properties reportedly remain at an elevated level.

\section{B. Structure of the Financial System}

5. The Czech financial system is relatively small and dominated by the banking sector (Table 3), particularly foreign banks. Assets of the financial system were around 133 percent of GDP as of end-2010, with the ratio of credit to GDP around 57 percent. Banking sector assets represent 84 percent of the financial institutions' assets. The banking system's assets grew rapidly in the run up to the crisis, but growth since 2009 has been moderate. The banking sector is concentrated; the 5 largest banks control 70 percent of total bank assets, and the three largest control 60 percent. As a result of large-scale privatizations, the largest banks are wholly or majority-owned subsidiaries of big European financial conglomerates. ${ }^{3}$

6. The nonbank financial institutions (NBFIs) are small, with limited linkages to banks. With households holding their savings mainly in banks, assets of insurance companies, pension funds, investment funds, credit unions (CUs), and other NBFIs account for only 16 percent of the total financial system assets. The insurance industry has a high level of foreign participation and concentration. The credit union sector is small, but has been rapidly growing, with a tripling of the balance sheets within the last three years. The capital market in the Czech Republic is shallow; investors have easy access to EU markets.

\section{Financial Stability Assessment}

\section{A. Performance of the Financial System}

7. The banking sector has a conservative balance sheet structure characterized by a high share of resident deposits and loans denominated in the local currency, the koruna. Only around one-fifth of loans are denominated in foreign currencies, compared to over 50 percent in Bulgaria, Croatia, Hungary, Latvia, and some other Central and Eastern European (CEE) countries, and almost all these loans are to corporates, which implies that indirect foreign exchange risk is relatively limited. In addition, unlike some other advanced or CEE countries, banks do not depend on wholesale or external funding (rather, the Czech banking sector is a net external creditor); credit growth is funded mainly by domestic

\footnotetext{
${ }^{3}$ The five largest banks have parents from Austria, Belgium, Italy, and France.
} 
deposits with the loan-to-deposit ratio of around 70 percent. Throughout the crisis, banks have reduced their leverage rather significantly (Table 4). 
Table 3. Financial System Structure, 2009-11

\begin{tabular}{|c|c|c|c|c|c|c|c|c|c|c|c|c|}
\hline & \multicolumn{4}{|c|}{2009} & \multicolumn{4}{|c|}{2010} & \multicolumn{4}{|c|}{ Jun-11 } \\
\hline & Number & $\begin{array}{c}\text { Total } \\
\text { assets (in } \\
\text { millions } \\
\text { CZK) }\end{array}$ & $\begin{array}{c}\% \text { of total } \\
\text { assets }\end{array}$ & $\%$ of GDP & Number & $\begin{array}{c}\text { Total } \\
\text { assets (in } \\
\text { millions } \\
\text { CZK) }\end{array}$ & $\begin{array}{c}\% \text { of total } \\
\text { assets }\end{array}$ & $\%$ of GDP & Number & $\begin{array}{c}\text { Total } \\
\text { assets (in } \\
\text { millions } \\
\text { CZK) }\end{array}$ & $\begin{array}{c}\% \text { of total } \\
\text { assets }\end{array}$ & $\%$ of GDP \\
\hline Banks & 39 & $4,094,626$ & 84.2 & 112.9 & 41 & $4,188,929$ & 83.5 & 114.2 & 44 & $4,266,749$ & 83.6 & 115.3 \\
\hline Of which: & & & & & & & & & & & & 0.0 \\
\hline Four largest banks & 4 & $2,361,651$ & 48.5 & 65.1 & 4 & $2,431,669$ & 48.4 & 66.3 & 4 & $2,458,335$ & 48.1 & 66.4 \\
\hline Domestically-controlled & 5 & 542,413 & 11.1 & 15.0 & 6 & 567,703 & 11.3 & 15.5 & 6 & 581,088 & 11.4 & 15.7 \\
\hline Foreign-controlled & 14 & $2,943,858$ & 60.5 & 81.2 & 14 & $3,025,254$ & 60.3 & 82.5 & 15 & $3,076,701$ & 60.3 & 83.1 \\
\hline State-owned & 2 & 111,868 & 2.3 & 3.1 & 2 & 122,942 & 2.4 & 3.4 & 2 & 130,965 & 2.6 & 3.5 \\
\hline Branches of foreign banks & 18 & 496,487 & 10.2 & 13.7 & 19 & 473,030 & 9.4 & 12.9 & 21 & 477,996 & 9.4 & 12.9 \\
\hline Building Societies & 5 & 457,084 & 9.4 & 12.6 & 5 & 470,200 & 9.4 & 12.8 & 5 & 464,576 & 9.1 & 12.6 \\
\hline Non Bank Financial Institutions & 263 & 770,565 & 15.8 & 21.3 & 269 & 827,327 & 16.5 & 22.6 & 290 & 840,824 & 16.5 & 22.7 \\
\hline $\begin{array}{l}\text { Insurance companies } \\
\text { Of which: }\end{array}$ & 52 & 396,432 & 8.1 & 10.9 & 52 & 426,474 & 8.5 & 11.6 & 53 & 429,899 & 8.4 & 11.6 \\
\hline Life insurance & 7 & $\mathrm{n} / \mathrm{a}$ & $\mathrm{n} / \mathrm{a}$ & $\mathrm{n} / \mathrm{a}$ & 7 & $\mathrm{n} / \mathrm{a}$ & $\mathrm{n} / \mathrm{a}$ & $\mathrm{n} / \mathrm{a}$ & 7 & $\mathrm{n} / \mathrm{a}$ & $\mathrm{n} / \mathrm{a}$ & $\mathrm{n} / \mathrm{a}$ \\
\hline Non Life insurance & 29 & $\mathrm{n} / \mathrm{a}$ & $\mathrm{n} / \mathrm{a}$ & $\mathrm{n} / \mathrm{a}$ & 30 & $\mathrm{n} / \mathrm{a}$ & $\mathrm{n} / \mathrm{a}$ & $\mathrm{n} / \mathrm{a}$ & 31 & $\mathrm{n} / \mathrm{a}$ & $\mathrm{n} / \mathrm{a}$ & $\mathrm{n} / \mathrm{a}$ \\
\hline Life and Non life insurance & 16 & $\mathrm{n} / \mathrm{a}$ & $\mathrm{n} / \mathrm{a}$ & $\mathrm{n} / \mathrm{a}$ & 15 & $\mathrm{n} / \mathrm{a}$ & $\mathrm{n} / \mathrm{a}$ & $\mathrm{n} / \mathrm{a}$ & 15 & $\mathrm{n} / \mathrm{a}$ & $\mathrm{n} / \mathrm{a}$ & $\mathrm{n} / \mathrm{a}$ \\
\hline Pension funds & 10 & 215,873 & 4.4 & 6.0 & 10 & 232,427 & 4.6 & 6.3 & 10 & 239,698 & 4.7 & 6.5 \\
\hline Investment funds & 110 & 118,025 & 2.4 & 3.3 & 117 & 123,735 & 2.5 & 3.4 & 117 & 121,445 & 2.4 & 3.3 \\
\hline Investment companies (non banks) & 28 & 22,587 & 0.5 & 0.6 & 25 & 24,758 & 0.5 & 0.7 & 22 & 25,300 & 0.5 & 0.7 \\
\hline Credit unions & 17 & 17,649 & 0.4 & 0.5 & 14 & 19,934 & 0.4 & 0.5 & 14 & 24,481 & 0.5 & 0.7 \\
\hline Total Financial Institutions & 302 & $4,865,191$ & 100.0 & 134.2 & 310 & $5,019,608$ & 100.0 & 136.9 & 334 & $5,106,175$ & 100.0 & 138.0 \\
\hline Memo items: GDP (millions CZK) & & & & $3,625,865$ & & & & $3,667,429$ & & & & $3,700,700$ \\
\hline
\end{tabular}

Source: Czech National Bank 
8. As a result, the Czech banks proved generally resilient to the effects of the ongoing global turmoil. The Czech banking sector is one of the few in the region where no exceptional state measures were needed. The relaxation of monetary policy was sufficient to ensure adequate liquidity. The provision of emergency liquidity by the European Central Bank (ECB) and support by their home governments benefitted some troubled parent banks and helped shield Czech subsidiaries from induced financial distress.

9. Banks report strong capital, liquidity, and profitability (Table 4 and Figure 1). Although banks were affected by the weakened economy, with the NPL ratio climbing to 6.4 percent as of end-March 2011 (from 3.2 percent as of end-2008), the capitalization and profitability indicators remained solid. The capital adequacy ratio, which is mainly made up of Tier I capital, increased from 12.3 percent in 2008 to 15.9 percent in June 2011, reflecting profit retention, slower credit growth, higher share of claims on government, and some capital relief (especially on mortgage loans) arising from the move to Basel II. The aggregate liquidity ratios, which declined in 2008 , have recovered and remained broadly stable or even improved.

10. The performance of NBFIs has been mixed. Insurance companies continue to report profitable results and adequate capitalization. Building societies face specific challenges relating to the planned reduction in government subsidies. The performance of the small, but fast-growing, CU sector is weak, with a high share of NPLs and a very low loan-loss provisioning ratio.

\section{B. Risks to Financial Stability}

11. Risks to financial stability remain heightened given the uncertain European and global macroeconomic and financial outlook. The macroeconomic recovery that started in 2010 is losing momentum given recent developments in the Euro Area. Net exports - closely linked to growth performance of the main trading partner Germany - and fixed investments, which drove the recovery, are likely to be negatively impacted by the recent deterioration of the global outlook. At the same time, public and private sector consumption have been declining recently given fiscal consolidation and the weak labor market trends. The main risks to financial stability stem from abroad (see also Appendix II):

- $\quad$ The developments in recent months increased concerns of a recession in the main trading partners of the Czech Republic. A recession in the Euro Area would derail the domestic recovery in the Czech Republic, which would subsequently negatively affect the health of financial institutions. 
Table 4. Financial Soundness Indicators of the Banking Sector, 2008-2010

\begin{tabular}{|c|c|c|c|c|c|c|}
\hline & 2008 & 2009 & Mar-10 & Jun-10 & Sep-10 & Dec-10 \\
\hline \multicolumn{7}{|l|}{ Capital } \\
\hline Regulatory capital to risk-weighted assets & 11.57 & 13.97 & 14.18 & 14.97 & 15.51 & 15.27 \\
\hline Regulatory Tier 1 capital to risk-weighted assets & 11.10 & 12.57 & 12.76 & 13.69 & 14.15 & 13.86 \\
\hline Capital to assets & 5.46 & 6.09 & 6.11 & 6.52 & 6.62 & 6.49 \\
\hline \multicolumn{7}{|l|}{ Profitability } \\
\hline Return on assets & 1.10 & 1.45 & 1.53 & 1.40 & 1.35 & 1.25 \\
\hline Return on equity & 20.68 & 26.36 & 25.15 & 22.46 & 21.36 & 19.70 \\
\hline Interest margin to gross income & 64.96 & 55.79 & 59.41 & 62.52 & 62.62 & 63.12 \\
\hline Noninterest expenses to gross income & 51.24 & 41.96 & 42.42 & 43.96 & 45.28 & 46.79 \\
\hline Trading income to total income & -4.79 & 9.46 & 8.12 & 5.31 & 4.70 & 4.56 \\
\hline Personnel expenses to noninterest expenses & 40.18 & 40.5 & 40.19 & 40.49 & 39.43 & 39.76 \\
\hline \multicolumn{7}{|l|}{ Liquidity } \\
\hline Liquid assets to total assets & 25.80 & 27.05 & 30.39 & 30.04 & 31.28 & 29.43 \\
\hline Liquid assets to short-term liabilities & 70.30 & 69.97 & 76.18 & 73.84 & 77.32 & 71.12 \\
\hline Customer deposits to total (noninterbank) loans & 125.59 & 128.21 & 131.41 & 131.57 & 133.19 & 129.61 \\
\hline Foreign-currency-denominated loans to total loans & 21.82 & 21.20 & 19.90 & 21.26 & 19.47 & 21.55 \\
\hline \multicolumn{7}{|l|}{ Foreign-currency-denominated assets to total assets } \\
\hline \multicolumn{7}{|l|}{ Foreign-currency-denominated deposits to total deposits } \\
\hline Foreign-currency-denominated liabilities to total liabilities & 16.36 & 14.15 & 13.4 & 14.61 & 13.43 & 14.29 \\
\hline \multicolumn{7}{|l|}{ Sensitivity to market risk } \\
\hline Net open position in foreign exchange to capital & 3.94 & 0.51 & 0.57 & -0.43 & 0.66 & 0.37 \\
\hline Gross asset position in financial derivatives to capital & 98.39 & 53.99 & 54.15 & 55.88 & 54.71 & 43.18 \\
\hline Gross liability position in financial derivatives to capital & 93.87 & 50.92 & 51.09 & 53.70 & 51.41 & 41.23 \\
\hline Net open position in equities to capital & 15.67 & 8.26 & 8.40 & 8.28 & 7.63 & 8.08 \\
\hline
\end{tabular}

Source: The CNB. 
Figure 1. Comparative Soundness of the Banking System
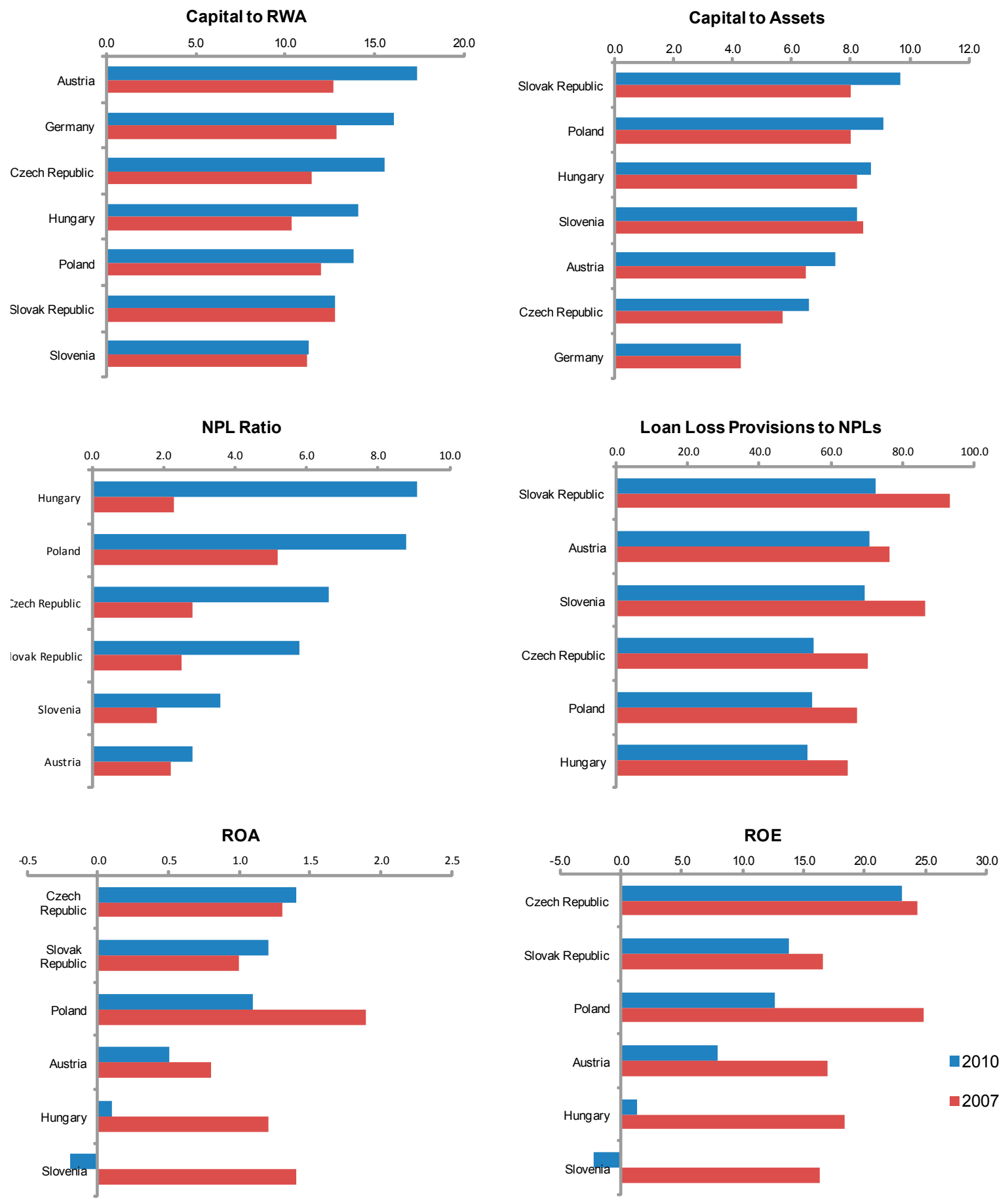

Source: The Global Financial Stability Report (GFSR). 
- $\quad$ Similarly, recent developments and risks facing EU economies, along with increasing risks in the US and emerging market economies, have raised concerns about a global "DD" scenario, which could result in a significant slowdown in economic activities in the Czech Republic, especially with the reduced space for policy response on the fiscal and monetary side compared to the position at the beginning of the global financial crisis.

- $\quad$ The deterioration in the financial condition of specific foreign parent banks may have repercussions to their Czech subsidiaries. Some parent banks could be forced to deleverage, including at the subsidiary level, upstream substantial parts of their earnings as well as liquidity, or sell their Czech subsidiary under unfavorable market conditions. In the case that parent banks encourage subsidiaries to deleverage in order to free additional capital and liquidity, the Czech economy could be adversely affected, including through feedback effects on banks' asset quality. Reputational risk arising from the deterioration of the solvency or liquidity of a parent bank could raise the subsidiary's cost of funding or even trigger a run on deposits.

- $\quad$ The Czech banks are exposed to the domestic real estate sector in the form of mortgage loans and loans to construction companies. While the real estate market risks are contained under current macroeconomic conditions thanks to the dominance of owner occupiers among the borrowers and prudent loan-to-value ratios, it could act as a channel that amplifies the impact of the risks mentioned above.

\section{Stress Tests of Banks}

\section{Methodology and assumptions}

12. The stress tests covered solvency, liquidity, and contagion risks. The tests comprised (a) top-down (TD) stress tests of the entire banking system based on the CNB's framework using quarterly data; (b) TD stress tests of the entire banking system based on an IMF framework using annual data, and (c) bottom-up (BU) stress tests performed by the largest banks (representing around 80 percent of the system in terms of assets) using quarterly data. Appendix III provides more details.

- $\quad$ The solvency tests were based on balance sheet approaches and focused on the behavior of the banking system under two macroeconomic scenarios. The solvency risks included credit risks, market risks, funding risks, concentration risk, and sovereign risk. The following adverse macroeconomic scenarios were considered: (a) a DD recession (moderate and severe); and (b) a prolonged period of low economic growth. ${ }^{4}$ In the TD test based on the IMF framework, the time horizon

\footnotetext{
${ }^{4}$ In historical terms, using cross-country evidence, the likelihood for the scenarios is about 15 percent for the moderate DD, 1-2 percent for the severe DD, and 5 percent for the slow growth scenario.
} 
covered five years to better capture the full impact of stress and simulate the introduction of Basel III (Figure 2). Dynamic effects were captured through the increase in funding costs conditional on capitalization (using evidence observed during the crisis) and stress of parent exposure under the severe DD recession scenario.

- $\quad$ The liquidity tests focused on funding shocks, accounting for the counterbalancing capabilities of banks. ${ }^{5}$ The BU stress tests were used as a cross-check against TD results based on supervisory data. A moderate and a severe scenarios were considered, with the latter simulating more adverse conditions than those prevailing after the collapse of Lehman brothers in 2008.

- $\quad$ The contagion tests simulated a partial loss on exposures to parent banks under a severe double dip scenario. ${ }^{6}$ It was assumed that 40 percent of the gross exposure of banks to their parent would be lost (the average exposure of large Czech banks to their parents is around 50 percent of their capital).

\footnotetext{
${ }^{5}$ To counterbalance the outflow of funding, fire sales of liquid assets were simulated. Only cash and sovereign bonds were assumed to remain liquid, and government bonds were assumed to be sold at a discount of 20 percent, which is very conservative.

${ }^{6}$ Interbank exposures across the Czech banks are limited, so tests to simulate potential interbank contagion channels were not considered.
} 
Figure 2. GDP Trajectories Under Different Stress Test Scenarios 1/

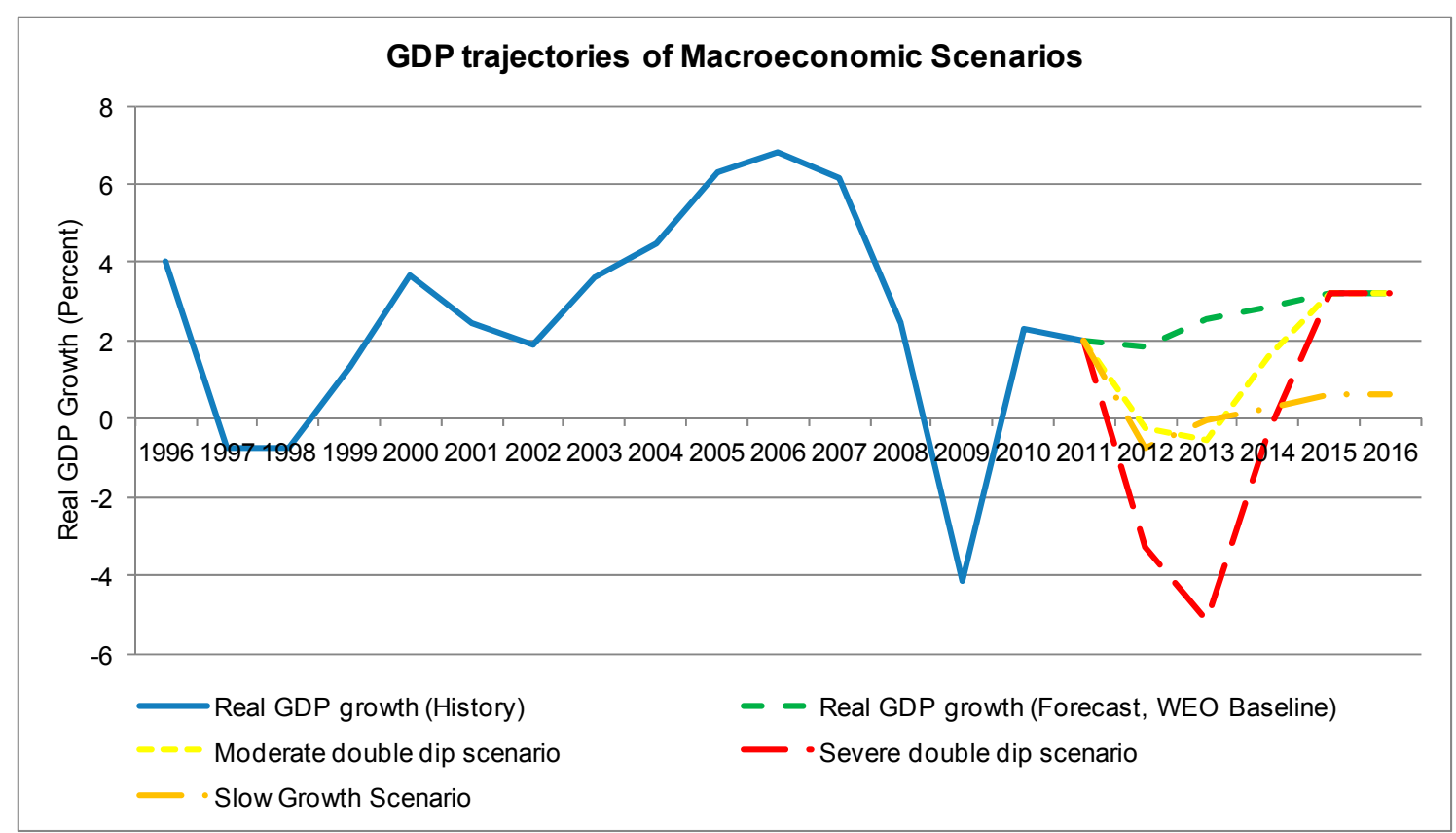

Source: IMF staff.

1/ the baseline growth numbers are from the WEO of Fall 2011.

\section{Results}

\section{On a standalone basis - or excluding contagion from parents- the Czech} banking system is resilient against substantial shocks (Figure 3). ${ }^{7}$ Measured against current and future supervisory standards (Basel III), Czech banks are, with only a few exceptions among the smaller banks, sufficiently capitalized to withstand stress scenarios. ${ }^{8}$ The favorable income position, which provides banks with a considerable first line of defense against their main risk, along with high current capital buffers, enhances system resilience. In addition, Czech banks' direct exposure to the riskiest sovereign debt exposures in the Euro Area is limited, though they are indirectly exposed through their parents' exposures. Name concentration of the customer loans is low, especially for the largest banks, though less so for the publicly-owned banks and some of the smaller banks. Banks have very limited exposure to peripheral Europe.

\footnotetext{
${ }^{7}$ The outcome of stress tests is broadly consistent across different methodologies. The main difference between the CNB and the IMF frameworks relates to the projection of capitalization dynamics using the satellite models.

${ }^{8}$ Basel III is expected to have a limited impact on Czech banks because of their high level of high-quality capital.
} 
14. Only the severe DD scenario brings the system close to the regulatory minimum capitalization. Under this scenario, the small banks are hit hardest, together with the building societies, but also some of the largest banks experience a substantial drop in capitalization. As for the moderate DD and prolonged low growth scenarios which subject the banks to substantial stress, the system does not experience a significant drop of capitalization, and many banks remain profitable. Banks can absorb a reduction of their lending margins, including under severe stress.

15. Direct contagion at the parent level could be significant. Under a severe DD scenario combined with a loss on exposure to their parents (both for the TD CNB model and the TD IMF model), the system would become slightly undercapitalized due to the simultaneous occurrence of credit losses and reduced pre-impairment income. A recapitalization of banks of up to 2 percent of GDP would be needed. However, the likelihood of materialization of such a combined scenario is considered to be low.

\section{Ample liquidity puts the vast majority of banks into a position to withstand} substantial stress (Figure 4). The Czech banks benefit from a relatively low loan-to-deposit ratio (70 percent on average), and hold about 20 percent of their assets in domestic government bonds, which allows to generate liquidity if needed. The results of the TD tests are consistent with the BU tests, leaving most banks with considerable buffers even after stress (including additional upstreaming of liquidity to their parents up to the regulatory limit) except for a few medium-sized banks. 
Figure 3. Outcome of Solvency Stress Tests for the Czech Banking System
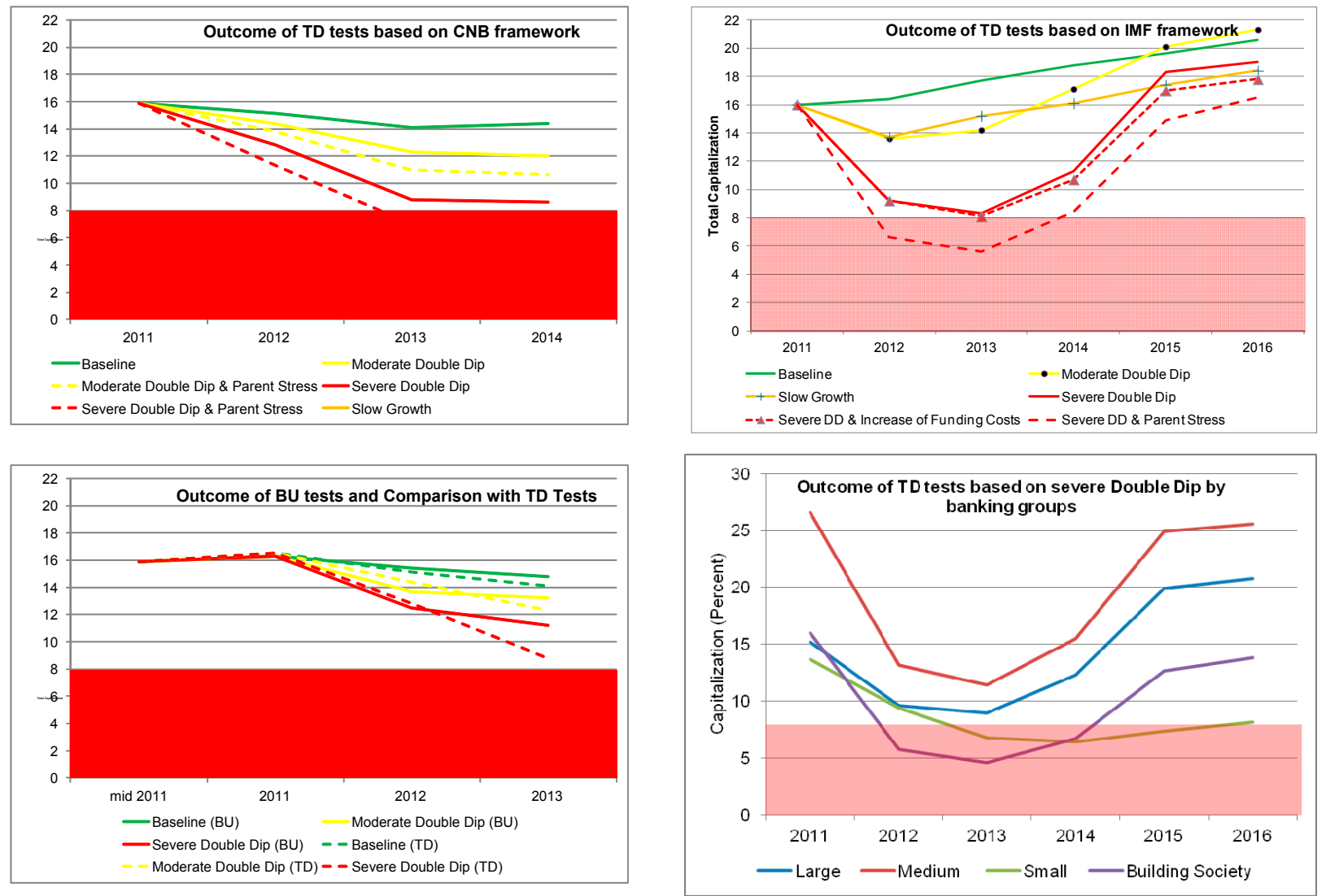

\section{Figure 4. Outcome of Liquidity Stress Tests for the Czech Banking System}
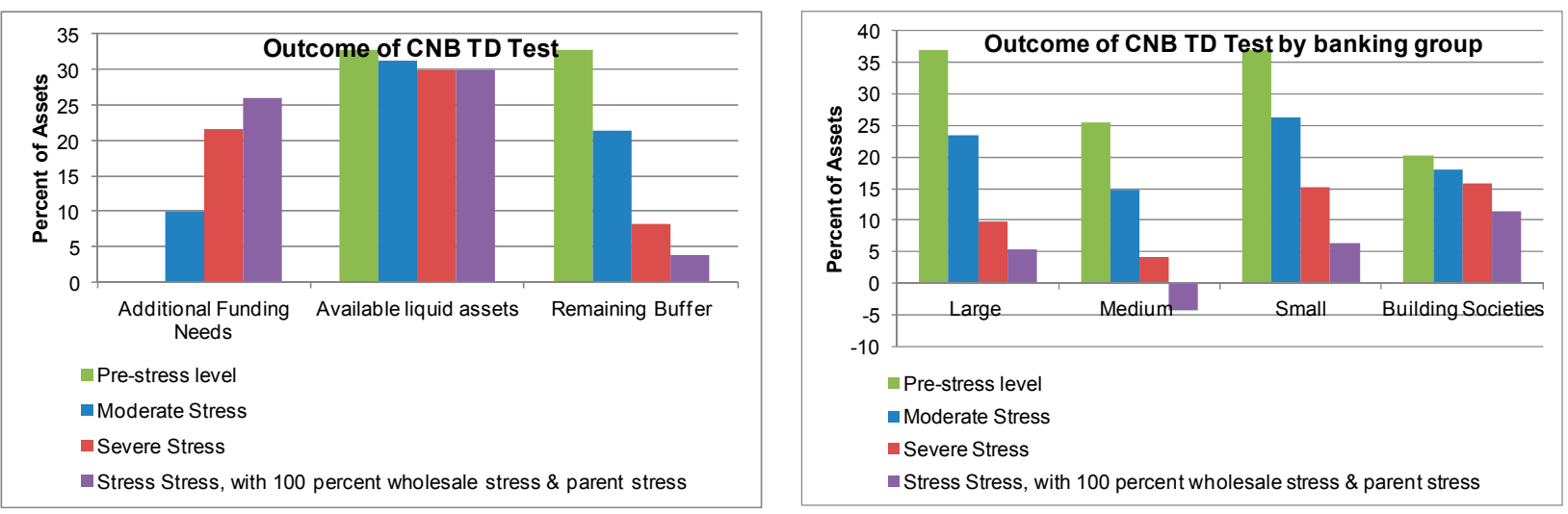


\section{The Financial Policy Framework}

\section{A. The Mandate of the CNB}

\section{The Czech authorities should consider strengthening the CNB's financial} stability mandate. According to the current formulation of the law, the CNB's objective is to ensure price stability, while financial stability is one of the supporting elements of achieving price stability. Elevating the financial stability to an explicit objective- -without prejudice to the primary objective of price stability - would strengthen the mandate of the CNB on financial stability (including microprudential and macroprudential supervision, as well as crisis management and bank resolution) and establish a stronger accountability framework.

\section{B. Macroprudential Framework}

18. The CNB has a solid macroprudential policy framework in place. As the integrated financial supervisor since 2006, the CNB has developed various internal tools and processes for detecting and monitoring systemic financial risks. However, no macroprudential policy instruments have ever been used, though they may have been useful during the boom period. In future, putting in place a mechanism for taking timely action could help align incentives. Such a mechanism could be formalized with (a) a pre-set schedule for CNB Board meetings on macroprudential policies, to discuss systemic risks, and to decide whether regulatory or other action is needed; (b) a recommendation to be made by the Financial Stability Department on whether and what policy action is needed; and (c) a press statement released soon after the Board meeting, explaining the nature of the risk and the consequent policy action (or inaction) to address this risk. Such an approach would be important to help enhance the CNB's accountability for achieving its financial stability objective.

\section{There is also room to strengthen analysis of risks to financial stability identified}

above. For example, for risks arising from contagion from parent banks, stress tests can help assess whether existing capital and liquidity buffers are adequate, and whether supervisory action is needed. The CNB should also strengthen its toolkit to mitigate the risk of real estate price bubbles and credit booms should they reemerge. Some of these tools have been prescribed under Basel III and CRD-IV, such as counter-cyclical capital buffers, capital charges for systemically important financial institutions, and liquidity requirements.

20. An enhanced dialogue between the CNB and the ministry of finance (MOF) would help take macroprudential policy actions in a timely and coordinated fashion. There is scope to improve the coordination of policies; for example, those affecting the housing market, in which tax and other policies can significantly affect the incentives for borrowing. Adjustments in such policies could also be considered for financial stability purposes. 


\section{Regulation and Supervision}

\section{Overall, the Czech legislation, regulations, and guidelines for banks are} comprehensive and in line with sound international practices, but supervision could be more intrusive. ${ }^{9}$ Reflecting resource constraints and the risk-based supervision approach, supervision focuses on the largest banks and entities with higher risk profile or corporate governance deficiencies. Such an approach is critically dependent on close and frequent monitoring and verification by the CNB. There is scope to conduct more intrusive supervision, including in the area of AML/CFT. For example, the CNB has relatively intense off-site monitoring of the major banks both domestically and through the existing supervisory colleges. Nevertheless, three years or more may pass between full inspections even of large banks. The frequency of on-site inspections (both targeted and full) is inadequate to ensure full understanding of developments in banks.

\section{Although the CNB has various processes for identifying vulnerabilities in banks,} no structured process exists for preemptive supervisory action. There are no formally stipulated early triggers for supervisory action; the only explicit trigger which mandates the CNB to take specified action is when a bank's capital declines below two-thirds of regulated minimum capital. The CNB should introduce a structured framework for early intervention (or decision not to intervene), based on quantitative as well as judgmental criteria.

\section{Large exposure limits and exemptions are high and constitute additional risks to} the banks. The CNB applies a 100 percent of bank capital limit for exposures from the Czech subsidiary to its EU-based parent bank, sister bank, or investment bank. Though this is in line with EU rules, such high limits as well as some exemptions constitute additional risks to the banks. The globally agreed Basel rules limit large exposures to a single or to connected counterparties to 25 percent of a bank's capital funds. ${ }^{10}$

\section{The current uncertain external environment calls for close monitoring of} subsidiaries of foreign banks and potential use of prudential measures. In August 2011, the CNB introduced extraordinary monitoring through weekly reporting of subsidiaries' liquidity position and the exposures towards their parent companies. Such enhanced monitoring could usefully be supported by more frequent on-site visits of the subsidiaries, commensurate with the developments at the level of their parent banks. Moreover, in case of a material deterioration of the condition of parent banks, the CNB may want to consider the deployment of firm-specific prudential measures, such as increasing capital and liquidity requirements, requiring pre-approval of material intra-group transactions, or reducing

\footnotetext{
${ }^{9}$ See Appendix I for more details.

${ }^{10}$ Following the FSAP mission, the authorities indicated their intention to reduce the limit on intra-group exposures from 100 percent to 50 percent of bank capital from July 2012.
} 
intra-group limits. The CNB should continue to take a proactive role in cross-border cooperation with relevant home country supervisors.

25. The effectiveness of the CNB's supervision of financial conglomerates should be strengthened to allow effective and timely identification of potential contagion risks. In particular, the CNB should have an explicit legal authority to supervise directly all entities (including nonregulated entities) within a conglomerate. The CNB should also formulate policy guidelines to determine the basis and necessity for conducting on-site inspection of nonregulated entities as part of its supplementary supervision and an implementation plan, including the adequacy of supervisory resources.

26. There is a need to overhaul the regulatory framework for CUs. Recent strong growth in this sector was boosted by the higher deposit rates and the level of deposit insurance on par with bank deposits. There are concerns that further defaults in the CU sector may deplete the DIF's resources. A problematic CU sector also poses reputational risks to the CNB. The CU sector should be restructured by converting some of the existing CUs into banks with appropriate fit and proper criteria, while restricting the activities of the remaining CUs to those of typical CUs around the world (clearly defined membership criteria, not-forprofit objective, etc.

\section{Crisis Management and Resolution}

27. The institutional framework for crisis management and resolution is broadly appropriate, although some of its elements should be improved. First, the institutional coordination between the CNB and the MOF should be strengthened by activating and updating the existing Memorandum of Understanding (MOU) to provide for more frequent, formal coordination on crisis management-related issues. ${ }^{11}$ In addition, the DIF should be included in crisis management coordination mechanisms, as early information with the DIF is necessary for it to fulfill effectively its role and responsibilities. Second, the authorities should periodically conduct crisis simulation analysis, which would allow them to assess ex ante the appropriateness of various policy responses under different circumstances.

28. The framework for using public funds to provide exceptional support to the banking sector should be operationalized. The existing framework provides for a possibility of budget support to banks. However, the authorities should ensure that they have appropriate policy guidelines and plans of action in place that would enable them to swiftly provide such support in the event that systemic financial stability is at stake. This would include, for example, preparing expedited procedures to establish and capitalize a bridge

\footnotetext{
${ }^{11}$ Under the Crisis Management MOU, the Crisis Management Group comprising representatives from the MOF and the CNB is obliged to meet on an annual basis. Currently, the DIF is not a party to the Crisis Management MOU.
} 
bank (including obtaining standing budgetary authorization to do so) and developing clear policy criteria for the extension of emergency liquidity assistance by the CNB.

\section{The threshold relating to the appointment of a conservator should be more}

flexible. The Act on Banks now authorizes the CNB to appoint a conservator to a bank only where "shortcomings in a bank's activities endanger the stability of the banking or financial system." While conservatorship is not a panacea and the appointment of a conservator requires careful consideration, the threshold that has to be satisfied under current legislation should be reconsidered, as ex ante determinations of systemic importance are difficult to make - even the failure of a small bank could, under certain circumstances, jeopardize the stability of the financial system as a whole. A better approach would allow for the appointment of a conservator under qualitative (e.g., the activities or condition of the bank poses serious risks to the bank's depositors) and quantitative (e.g., based on capital or liquidity requirements) criteria that are sufficiently flexible to allow the CNB to respond to a range of problems.

\section{The ability of the DIF to accomplish its objectives should be strengthened in} several aspects. First, the governance structure of the DIF should be improved by limiting the participation of active industry representatives on the Board. Second, the financial means of the DIF should be increased by raising the target size of the fund (which is now 1.5 percent of insured deposits) and streamlining backstop funding arrangements with the MOF. ${ }^{12}$ As it currently stands, the failure of a single mid-size bank could deplete the resources of the DIF. Related to the necessary increase of the fund, the authorities could consider introducing risk-based contributions. Third, the trigger for payout should be clarified to ensure consistent determination of when payouts should be made (e.g., based on the revocation of an institution's license) and timely compensation of depositors in line with their expectations of a 20 working day payout. ${ }^{13}$ Fourth, the DIF should be able to advance funds to facilitate purchase and assumption transactions involving the transfer of insured deposits to a healthy institution, on a least-cost basis. Finally, the insolvency act should be amended to allow for preferential treatment for claims of insured depositors. This could promote more effective recoveries by the DIF.

\section{The dominance of foreign banks makes it essential for the Czech authorities to actively participate in cross-border crisis management groups (CMG). Amongst other} things, the CMGs seek to assess and discuss specific issues and barriers to coordinated action that may arise when handling severe stress at specific firms, and share information on groups

\footnotetext{
${ }^{12}$ At the time of the mission, the MOF and the DIF were negotiating an arrangement on potential bond issuances and other modalities to provide the DIF with backstop funding, if and when necessary.

${ }^{13}$ Currently, a payout is made after the CNB provides written notification to the DIF that the depositors' funds are unavailable. However, there is no framework for determining when notification is made or when the depositors' funds are unavailable, which could result significant delays between the time when the bank is closed and the time when the depositors' can access their funds.
} 
that may be pertinent in crisis situations. Such groups will provide the Czech authorities access to discussions of the recovery and resolution plans of banking groups. The CNB participated in the inaugural meetings of groups for various banks active in the Czech Republic, but has so far refrained from signing written agreements on crisis management, as it prefers to await the finalization of the EU framework for bank recovery and resolution. 


\section{APPENDIX I. 2002 FSAP MAIN RECOMMENDATIONS: STATUS OF IMPLEMENTATION}

\begin{tabular}{|c|c|}
\hline Recommendations & Status \\
\hline Completing the transformation of banks and enterprises. & Implemented \\
\hline $\begin{array}{l}\text { Finalization of the carve-out of NPLs arising from the recent resale of IBP and the } \\
\text { completion of the sale of KB. }\end{array}$ & Implemented \\
\hline Acceleration of the pool sales of bad loans initiated by the KOB group in early 2001. & Not Implemented \\
\hline $\begin{array}{l}\text { Enhancing efforts to improve the collateral and insolvency regimes to expedite } \\
\text { enterprise restructuring and bank workouts, and improve the auction price of NPLs. }\end{array}$ & Implemented \\
\hline Introduction of full tax deductibility of mandatory provisions. & Implemented \\
\hline \multicolumn{2}{|l|}{ Banking supervision } \\
\hline $\begin{array}{l}\text { A need to move more swiftly toward a risk-based approach to supervision, targeting } \\
\text { resources on the key risks facing the banks on both a sector and individual bank } \\
\text { basis. }\end{array}$ & Implemented \\
\hline $\begin{array}{l}\text { Application of capital charges on a consolidated basis for other risks (currently credit } \\
\text { risk only) and the introduction of consolidated supervision for financial holding } \\
\text { companies and mixed holding companies. }\end{array}$ & Implemented \\
\hline $\begin{array}{l}\text { Regulations need to be made more specific with respect to some of the credit risk } \\
\text { governance aspects including a bank board approved loan and investment policy. }\end{array}$ & Implemented \\
\hline $\begin{array}{l}\text { Requirements for risk management processes need to be set out explicitly in the } \\
\text { regulations. }\end{array}$ & Implemented \\
\hline $\begin{array}{l}\text { Anti-money laundering procedures need to be made more explicit in CNB } \\
\text { regulations; and }\end{array}$ & Implemented \\
\hline $\begin{array}{l}\text { Supervisory skills and resources to assess market risk, audit computer based } \\
\text { systems, and evaluate risk management systems could be further strengthened. }\end{array}$ & Implemented \\
\hline \multicolumn{2}{|l|}{ Safety net } \\
\hline $\begin{array}{l}\text { The authorities should consider a public restatement of the role of the DIF in the } \\
\text { financial system and strengthen its public credibility. }\end{array}$ & Implemented \\
\hline $\begin{array}{l}\text { The DIF needs to consider its own funding arrangements, given the expected } \\
\text { removal of the obligation of the authorities to cover any shortfall in the Fund's } \\
\text { reserves; and }\end{array}$ & Pending \\
\hline $\begin{array}{l}\text { The DIF also needs to engage in regular dialogue with banking supervisors and to } \\
\text { monitor closely any adverse developments in relation to individual institutions that } \\
\text { might represent a future obligation on its reserves. }\end{array}$ & Implemented \\
\hline \multicolumn{2}{|l|}{ Credit unions } \\
\hline $\begin{array}{l}\text { Credit union membership in the Czech Republic should be limited to a "common } \\
\text { bond" (e.g., memberships to be contained within a specific geographic area or work } \\
\text { place). }\end{array}$ & Not implemented \\
\hline $\begin{array}{l}\text { The CUSA should have rule-making powers and should be made independent of } \\
\text { the MOF. At a prudential level, the CUSA should have direct responsibility for } \\
\text { stipulating minimum solvency "large exposures" and liquidity requirements. }\end{array}$ & Implemented \\
\hline $\begin{array}{l}\text { Given its limited resources the CUSA should also move to risk-based supervision, } \\
\text { targeting resources to the higher impact more complex unions, and its supervisory } \\
\text { capacity also requires immediate attention and strengthened. }\end{array}$ & Implemented \\
\hline \multicolumn{2}{|l|}{ Securities regulations } \\
\hline $\begin{array}{l}\text { Regulatory independence and supervisory capacity should be enhanced through a } \\
\text { fundamental change in approach, from formal monitoring of compliance to a more }\end{array}$ & Implemented \\
\hline
\end{tabular}




\begin{tabular}{|c|c|}
\hline Recommendations & Status \\
\hline \multicolumn{2}{|l|}{$\begin{array}{l}\text { proactive, focused and risk-based supervisory approach. The strengthening of the } \\
\text { supervisory function will also require a more efficient use of self-regulation } \\
\text { organizations, which will allow the Czech Securities Commission (CSC) to } \\
\text { concentrate its resources more effectively. }\end{array}$} \\
\hline $\begin{array}{l}\text { The bar for listing requirements should be lifted and higher standards for } \\
\text { client/broker relationships established. }\end{array}$ & Implemented \\
\hline $\begin{array}{l}\text { Risk-based liquid asset requirements for investment service companies should be } \\
\text { introduced. }\end{array}$ & Implemented \\
\hline $\begin{array}{l}\text { Transparency of securities regulation relating to investor rights protection should be } \\
\text { explicitly specified in relevant legislation and disclosed through the CSC's } \\
\text { publications. }\end{array}$ & Implemented \\
\hline \multicolumn{2}{|l|}{ Harmonization with EU legislation } \\
\hline $\begin{array}{l}\text { Mutual funds should publish detailed data on the composition of their portfolios, risk } \\
\text { exposures should be disclosed more adequately, the maximum limit on holdings of } \\
\text { individual equities should be reduced from } 10 \text { to } 5 \text { percent of net assets, forward } \\
\text { pricing should be introduced, assets valuation by depositories should be enhanced, } \\
\text { and independent valuations of illiquid assets should be introduced. }\end{array}$ & Implemented \\
\hline $\begin{array}{l}\text { The role of depositary institutions should be strengthened and their legal } \\
\text { responsibilities should be better enforced. }\end{array}$ & Implemented \\
\hline \multicolumn{2}{|l|}{ Insurance sector } \\
\hline The authorities should consider creating an autonomous supervisory agency & Implemented \\
\hline $\begin{array}{l}\text { Licensing criteria should be strengthened further by introducing formal conditions on } \\
\text { the financial strength of shareholders. }\end{array}$ & Implemented \\
\hline $\begin{array}{l}\text { Corporate governance rules should be strengthened, by imposing on the Boards } \\
\text { special responsibilities for the protection of policyholders. }\end{array}$ & Implemented \\
\hline $\begin{array}{l}\text { The appointment of auditors should be subject to approval by the supervisor, and } \\
\text { the supervisors should be notified of any change in the appointment of auditors. }\end{array}$ & Implemented \\
\hline $\begin{array}{l}\text { On-site inspections should be enhanced, which will require the upgrading of } \\
\text { expertise and professional skills. }\end{array}$ & Implemented \\
\hline Transparency practices relating to insurance regulation also require strengthening. & Implemented \\
\hline \multicolumn{2}{|l|}{ Pension funds } \\
\hline Adopting the mutual fund model for pension funds as soon as possible. & Ongoing \\
\hline $\begin{array}{l}\text { Requiring a minimum pension fund size for offering annuities directly, subject } \\
\text { annuity products to actuarial review, and introduce mandatory reserves proportional } \\
\text { to the size of assets under management. }\end{array}$ & Ongoing \\
\hline Abolish the guaranteed returns. & $\begin{array}{l}\text { Partially } \\
\text { implemented }\end{array}$ \\
\hline $\begin{array}{l}\text { Transferring the supervision over pension funds to the CSC in January 2002, as } \\
\text { proposed. However, the CSC will need to obtain the resources and skills to meet } \\
\text { this challenge successfully. }\end{array}$ & Implemented \\
\hline \multicolumn{2}{|l|}{ Development of financial markets. } \\
\hline $\begin{array}{l}\text { Setting and enforcing limits on primary dealers maximum ownership of a particular } \\
\text { issue bought directly or indirectly. }\end{array}$ & Implemented \\
\hline $\begin{array}{l}\text { Considering allowing primary dealers in from abroad with remote access to increase } \\
\text { competition in the market beyond local market participants. }\end{array}$ & Implemented \\
\hline & \\
\hline
\end{tabular}




\begin{tabular}{|l|l|}
\hline Recommendations & Status \\
\hline $\begin{array}{l}\text { Strengthening requirements for the disclosure by insiders of interests in transactions } \\
\text { and for shareholder approval. }\end{array}$ & Implemented \\
\hline $\begin{array}{l}\text { Ensuring further harmonization with international accounting standards, in } \\
\text { conjunction with the business community and accounting and auditing } \\
\text { representatives. }\end{array}$ & Implemented \\
\hline Strengthening the independence of external auditors & Implemented \\
\hline $\begin{array}{l}\text { Strengthening creditor rights by improving further the collateral and insolvency } \\
\text { regimes. }\end{array}$ & Implemented \\
\hline $\begin{array}{l}\text { Strengthening the capacity of the courts to provide effective and prompt resolution } \\
\text { of civil and criminal litigation, concerning the responsibilities of companies, directors, } \\
\text { managers, and auditors. }\end{array}$ & Ongoing \\
\hline & \\
\hline
\end{tabular}




\section{APPENDIX II. CZECH REPUBLIC: RISK ASSESSMENT MATRIX}

\begin{tabular}{|c|c|c|}
\hline $\begin{array}{l}\text { Nature/Source } \\
\text { of Main Risks }\end{array}$ & $\begin{array}{l}\text { Likelihood of Severe Realization } \\
\text { of Risk in the Next 1-3 Years }\end{array}$ & $\begin{array}{c}\text { Expected Impact on Financial Stability if } \\
\text { Risk is Realized }\end{array}$ \\
\hline $\begin{array}{l}\text { A double dip } \\
\text { recession }\end{array}$ & $\begin{array}{l}\text { Medium } \\
\text { - Despite the global recovery after } \\
\text { the height of the financial crisis in } \\
2008 / 09 \text {, the sovereign debt crisis } \\
\text { has increased uncertainties } \\
\text { substantially. The vulnerabilities of } \\
\text { the Western European sovereigns } \\
\text { (but also the U.S. and Japan), } \\
\text { together with a cooling down of } \\
\text { major emerging economies could } \\
\text { develop into a global DD recession } \\
\text { with adverse macrofinancial } \\
\text { feedback loops for the Czech } \\
\text { Republic. } \\
\text { - The macroeconomic and financial } \\
\text { conditions are particularly weak in } \\
\text { many European economies. This } \\
\text { could result in a full blown global } \\
\text { recession (severe DD) or a lighter } \\
\text { dip based on regional stress, which } \\
\text { could still be felt (moderate DD), } \\
\text { the former one with noteworthy } \\
\text { impact for the Czech Republic and } \\
\text { the latter one with some impact. }\end{array}$ & $\begin{array}{l}\text { Medium/High } \\
\text { - Depending on the severity of the shock, } \\
\text { the Czech economy could be hit harder } \\
\text { and for a longer time than in } 2008 \text { or at } \\
\text { least moderately, with slowed growth, } \\
\text { more unfavorable export markets, and a } \\
\text { drop in asset prices. The impact of } \\
\text { shocks could be amplified by } \\
\text { countercyclical fiscal policies. } \\
\text { - The shocks could be further amplified by } \\
\text { a reversal of capital flows. The pertinent } \\
\text { impact depends on the severity of the } \\
\text { macroeconomic shock and whether there } \\
\text { is flight-to-quality. } \\
\text { - Macroeconomic shocks would have } \\
\text { negative effects on banks' asset quality } \\
\text { (i.e., result in credit losses), first through } \\
\text { spillovers and then domestically if stress } \\
\text { persisted, and reduce banks' pre- } \\
\text { impairment income. Both effects could } \\
\text { lead to a substantial drop of capitalization } \\
\text { or a gradual reduction, respectively. The } \\
\text { concentration of banks' lending activities } \\
\text { in commercial real estate and mortgages } \\
\text { is particularly sensitive to a severe } \\
\text { macroeconomic shock, as is corporate } \\
\text { exposure. } \\
\text { terms of funding, resulting from concerns } \\
\text { over solvency of their parent banks, in } \\
\text { addition to being somewhat challenged } \\
\text { by Basel III effects. Lending margins } \\
\text { could shrink as a consequence of fiercer } \\
\text { competition for deposits, and reduce } \\
\text { banks' first line of defense against losses. }\end{array}$ \\
\hline $\begin{array}{l}\text { Prolonged slow } \\
\text { growth scenario }\end{array}$ & $\begin{array}{c}\text { High } \\
\text { - Ongoing uncertainty in global } \\
\text { financial markets could increase }\end{array}$ & $\begin{array}{l}\text { Medium } \\
\text { - Although the Czech Republic might } \\
\text { initially not be hit directly, it would feel the }\end{array}$ \\
\hline
\end{tabular}




\begin{tabular}{|c|c|c|}
\hline $\begin{array}{l}\text { Nature/Source } \\
\text { of Main Risks }\end{array}$ & $\begin{array}{l}\text { Likelihood of Severe Realization } \\
\text { of Risk in the Next } 1-3 \text { Years }\end{array}$ & $\begin{array}{c}\text { Expected Impact on Financial Stability if } \\
\text { Risk is Realized }\end{array}$ \\
\hline & $\begin{array}{l}\text { global risk aversion and reduce } \\
\text { capital flows (to banks and } \\
\text { corporates) away from countries } \\
\text { like the Czech Republic, which } \\
\text { have been perceived, to some } \\
\text { degree, as safe haven. } \\
\text { - Unless the potential shock } \\
\text { translates into a full blown } \\
\text { recession (see above), a (global) } \\
\text { tendency towards flight-to-quality } \\
\text { fuelled by persistent uncertainties } \\
\text { in Europe resulting from the } \\
\text { sovereign debt crisis could lead to } \\
\text { a period of stagnation, i.e., a period } \\
\text { of Japan-like conditions with } \\
\text { persistent low growth. }\end{array}$ & $\begin{array}{l}\text { slowdown in growth through its main } \\
\text { trade partners, especially Germany. } \\
\text { - Exchange rates against major currencies } \\
\text { and financial markets could face higher } \\
\text { volatility, and amplify the stress } \\
\text { conditions. } \\
\text { - In addition to the moderate to medium } \\
\text { level stress impact on banks' asset } \\
\text { quality and pre-impairment income, some } \\
\text { of the banks (especially those without } \\
\text { strong parent banks) could face higher } \\
\text { funding costs, resulting from competition } \\
\text { for deposits, and Basel III effects could } \\
\text { amplify the situation to some degree. }\end{array}$ \\
\hline $\begin{array}{l}\text { Failure of a } \\
\text { foreign parent } \\
\text { bank }\end{array}$ & $\begin{array}{l}\text { Medium } \\
\text { - In case of a materialization of } \\
\text { stress in the euro area as a result } \\
\text { of the sovereign debt crisis, parent } \\
\text { banks could be negatively affected, } \\
\text { which would have at least some } \\
\text { repercussions on the Czech } \\
\text { subsidiaries } \\
\text { - Recent stress test results by the } \\
\text { EBA (to reach core tier } 1 \text { ratios of } 9 \\
\text { percent) could amplify this stress } \\
\text { conditions at the parent level. }\end{array}$ & $\begin{array}{l}\text { High } \\
\text { - The failure of a parent of a relatively large } \\
\text { Czech bank would have systemic } \\
\text { repercussions. } \\
\text { - Some strains at parent banks could be } \\
\text { felt in the Czech Republic, with parents' } \\
\text { upstreaming capital and/or liquidity and } \\
\text { thus limiting the action space of the } \\
\text { subsidiaries. Reputational risk could put } \\
\text { pressure on liquidity and funding costs. In } \\
\text { principle, subsidiaries could also be } \\
\text { pressured to deleverage, which could } \\
\text { have some feedback effects on the } \\
\text { economy unless other banks increase } \\
\text { their market share at the same time. }\end{array}$ \\
\hline
\end{tabular}


APPENDix III. STRESS TeSt MATRIX: SOlVENCY AND LiQUidity RISKS

\begin{tabular}{|c|c|c|c|}
\hline \multirow[t]{2}{*}{ Domain } & \multicolumn{3}{|c|}{ Solvency Assumptions } \\
\hline & $\begin{array}{l}\text { Bottom-Up by Banks } \\
\text { (if applicable) }\end{array}$ & $\begin{array}{l}\text { Top-Down by Authorities } \\
\text { (if applicable) }\end{array}$ & $\begin{array}{c}\text { Top-down by FSAP Team } \\
\text { (if applicable) }\end{array}$ \\
\hline Institutions included & - 8 & - All banks & - All Banks \\
\hline Market share & $\begin{array}{l}\text { - Percentage of total } \\
\text { sector assets: } 80\end{array}$ & $\begin{array}{l}\text { - Percentage of total } \\
\text { sector assets: } 100\end{array}$ & $\begin{array}{l}\text { - Percentage of total } \\
\text { sector assets: } 100\end{array}$ \\
\hline $\begin{array}{l}\text { Data and baseline } \\
\text { date }\end{array}$ & - Banks' own data & - Supervisory & - Supervisory \\
\hline Methodology & $\begin{array}{l}\text { - Combination of banks' } \\
\text { own models and pre- } \\
\text { defined benchmarks } \\
\text { (oriented on CNB } \\
\text { framework, agreed with } \\
\text { mission) }\end{array}$ & $\begin{array}{l}\text { - CNB stress testing } \\
\text { framework }\end{array}$ & $\begin{array}{l}\text { IMF framework } \\
\text { (Schmieder, Puhr and } \\
\text { Hasan, 2011) }\end{array}$ \\
\hline Stress test horizon & - Consolidated & - Consolidated & - Consolidated \\
\hline Shocks & \multicolumn{3}{|c|}{$\begin{array}{l}\text { - } 2.5 \text { years (BU), } 3 \text { years (TD CNB); } 5 \text { years (TD IMF) } \\
\text { - Shocks based on GDP trajectories, other variables evolve conditional on GDP } \\
\text { (according to output of CNB's macro model) } \\
\text { - Double Dip (1 StD and 2.5 StD in historical terms), Slow Growth (cumulative 5- } \\
\text { year deviation equal to } 2 \mathrm{StD} \text {, only based on TD IMF framework) }\end{array}$} \\
\hline $\begin{array}{l}\text { Risks/factors } \\
\text { assessed }\end{array}$ & $\begin{array}{l}\text { Comprehensive } \\
\text { coverage of solvency } \\
\text { risks (Credit, Market, } \\
\text { income risks, fixed } \\
\text { income holdings of } \\
\text { banks in peripheral } \\
\text { Europe, funding risk) }\end{array}$ & $\begin{array}{l}\text { - Comprehensive } \\
\text { coverage of solvency } \\
\text { risks (Credit, Market, } \\
\text { income risks, fixed } \\
\text { income holdings of } \\
\text { banks in peripheral } \\
\text { Europe, funding risk, } \\
\text { concentration risk) }\end{array}$ & $\begin{array}{l}\text { - Comprehensive } \\
\text { coverage of solvency } \\
\text { risks (Credit, market, } \\
\text { income risks, fixed } \\
\text { income holdings of } \\
\text { banks in peripheral } \\
\text { Europe, funding risk, } \\
\text { concentration risk) }\end{array}$ \\
\hline $\begin{array}{l}\text { Calibration of risk } \\
\text { parameters }\end{array}$ & $\begin{array}{l}\text { - Credit losses, pre- } \\
\text { impairment income and } \\
\text { credit growth based on } \\
\text { satellite models, haircut } \\
\text { on GIIPS exposure and } \\
\text { funding risks based on } \\
\text { expert judgment } \\
\text { - Point in time risk } \\
\text { parameters for credit } \\
\text { risk parameters based } \\
\text { on banks' internal } \\
\text { ratings-based (IRB) } \\
\text { models, and proxies for } \\
\text { the other banks }\end{array}$ & $\begin{array}{l}\text { - Credit losses, pre- } \\
\text { impairment income and } \\
\text { credit growth based on } \\
\text { satellite models, haircut } \\
\text { on GIIPS exposure and } \\
\text { funding risks based on } \\
\text { expert judgment } \\
\text { - Point in time risk } \\
\text { parameters for credit } \\
\text { risk parameters based } \\
\text { on banks' IRB models, } \\
\text { and proxies for the } \\
\text { other banks }\end{array}$ & $\begin{array}{l}\text { - Credit losses, pre- } \\
\text { impairment income, } \\
\text { credit growth and } \\
\text { funding costs based on } \\
\text { satellite models; haircut } \\
\text { on GIIPS exposure and } \\
\text { funding risks based on } \\
\text { expert judgment } \\
\text { - Point in time risk } \\
\text { parameters for credit } \\
\text { risk parameters based } \\
\text { on banks' IRB models } \\
\text { and proxies for the } \\
\text { other banks } \\
\text { - Asset correlations were } \\
\text { assumed to be fixed } \\
\text { (i.e., not to decrease } \\
\text { with increasing PDs, } \\
\text { LGDs), based on } \\
\text { Schmieder, Puhr and }\end{array}$ \\
\hline
\end{tabular}




\begin{tabular}{|c|c|c|c|}
\hline \multirow[t]{2}{*}{ Domain } & \multicolumn{3}{|c|}{ Solvency Assumptions } \\
\hline & $\begin{array}{l}\text { Bottom-Up by Banks } \\
\text { (if applicable) }\end{array}$ & $\begin{array}{l}\text { Top-Down by Authorities } \\
\text { (if applicable) }\end{array}$ & $\begin{array}{c}\text { Top-down by FSAP Team } \\
\text { (if applicable) }\end{array}$ \\
\hline & & & Hasan (2011) \\
\hline $\begin{array}{l}\text { Behavioral } \\
\text { adjustments }\end{array}$ & $\begin{array}{l}\text { - Credit growth projected } \\
\text { by satellite model, pre- } \\
\text { defined payout } \\
\text { depending on income } \\
\text { after stress/capital } \\
\text { buffer on banks' IRB } \\
\text { models }\end{array}$ & $\begin{array}{l}\text { - Credit growth projected } \\
\text { by satellite model, pre- } \\
\text { defined payout } \\
\text { depending on income } \\
\text { after stress/capital } \\
\text { buffer }\end{array}$ & $\begin{array}{l}\text { - Credit growth projected } \\
\text { by satellite model, } \\
\text { assumption that capital } \\
\text { constraint banks (i.e., } \\
\text { those with capital } \\
\text { conservation buffers } \\
\text { less than } 2.5 \text { ppts } \\
\text { would fully retain profit), } \\
\text { otherwise in line with } \\
\text { evidence for the Czech } \\
\text { Republic }\end{array}$ \\
\hline $\begin{array}{l}\text { Regulatory } \\
\text { standards }\end{array}$ & $\begin{array}{l}\text { - Hurdle rates based on } \\
\text { Basel II/III minimum for } \\
\text { Total Capital and Tier } 1 \\
\text { (Core Tier } 1 \text { is basically } \\
\text { in line with Tier } 1 \text { ) } \\
\text { - Basel II/III IRB rules }\end{array}$ & $\begin{array}{l}\text { - Hurdle rates based on } \\
\text { Basel II/III minimum for } \\
\text { Total Capital and Tier } 1 \\
\text { (Core Tier } 1 \text { is basically } \\
\text { in line with Tier } 1 \text { ) } \\
\text { - Basel II/III IRB rules, \& } \\
\text { StA }\end{array}$ & $\begin{array}{l}\text { - Hurdle rates based on } \\
\text { Basel II/III minimum for } \\
\text { Total Capital and Tier } 1 \\
\text { (Core Tier } 1 \text { is basically } \\
\text { in line with Tier 1) } \\
\text { - Basel II/III (quasi-) IRB } \\
\text { rules, \& StA }\end{array}$ \\
\hline Results & $\begin{array}{l}\text { - CAR/shortfall, system } \\
\text { wide. } \\
\text { - Pass or fail; percentage } \\
\text { of assets that fail. }\end{array}$ & $\begin{array}{l}\text { - CAR/shortfall, system } \\
\text { wide. } \\
\text { - Pass or fail; percentage } \\
\text { of assets that fail. }\end{array}$ & $\begin{array}{l}\text { - CAR/shortfall, system } \\
\text { wide. } \\
\text { - Pass or fail; percentage } \\
\text { of assets that fail. }\end{array}$ \\
\hline
\end{tabular}

Source: IMF staff.

\begin{tabular}{|c|c|c|c|}
\hline \multirow[t]{2}{*}{ Domain } & \multicolumn{3}{|c|}{ Liquidity Assumptions } \\
\hline & Bottom-Up by Banks & Top-Down by Authorities & Top-down by FSAP Team \\
\hline Institutions included & - 8 & - All & \multirow{7}{*}{$\begin{array}{l}\text { NA } \\
\text { (Robustness checks } \\
\text { based on publicly } \\
\text { available data) }\end{array}$} \\
\hline Market share & - 80 & - 100 & \\
\hline $\begin{array}{l}\text { Data and baseline } \\
\text { date }\end{array}$ & - Banks' own data & - Supervisory data & \\
\hline Methodology & $\begin{array}{l}\text { Bank-run type test } \\
\text { based on two scenarios } \\
\text { (moderate and severe } \\
\text { bank-run, with } \\
\text { scenarios similar to } \\
\text { previous stress tests in } \\
\text { CNB, see technical } \\
\text { note for details) }\end{array}$ & $\begin{array}{l}\text { Bank-run type test, } \\
\text { based on two scenarios } \\
\text { (moderate and severe } \\
\text { bank-run, with } \\
\text { scenarios similar to } \\
\text { previous stress tests in } \\
\text { CNB, see technical } \\
\text { note for details); Basel } \\
\text { III ratio (LCR, NSFR) }\end{array}$ & \\
\hline Risks & $\begin{array}{l}\text { - Funding liquidity \& } \\
\text { market liquidity }\end{array}$ & $\begin{array}{l}\text { - Funding liquidity \& } \\
\text { market liquidity, } \\
\text { maturity mismatch } \\
\text { (NSFR) }\end{array}$ & \\
\hline $\begin{array}{l}\text { Regulatory } \\
\text { standards }\end{array}$ & - NA & $\begin{array}{l}\text { - Proxy for Basel III ratios } \\
\text { (LCR, NSFR) }\end{array}$ & \\
\hline Results & $\begin{array}{l}\text { - Pass rate (Liquidity } \\
\text { Position relative to } \\
\text { Assets) }\end{array}$ & $\begin{array}{l}\text { Pass rate (Liquidity } \\
\text { Position relative to } \\
\text { Assets) }\end{array}$ & \\
\hline
\end{tabular}

Source: IMF staff. 


\section{AnNex I. Summary Observance of the Basel Core Principles for EfFective BANKING SUPERVISION}

\section{A. Information and Methodology Used for Assessment ${ }^{14}$}

32. This assessment reflects the regulatory and supervisory framework in place as of the date of the completion of the assessment. An assessment of the effectiveness of banking supervision requires a review of the legal framework, both generally and specifically related to the financial sector, and a detailed examination of the policies and practices of the institutions responsible for banking supervision. The assessment was conducted in accordance with the revised Core Principles Methodology issued by the Basel Committee on Banking Supervision (Basel Committee) in October 2006. The assessment of compliance with each core principle (CP) is made on a qualitative basis to allow a judgment on whether the criteria are fulfilled in practice.

\section{B. Institutional and Macroeconomic Setting and Market Structure-Overview}

33. The Czech economy has weathered the crisis relatively well so far. Limited external financing needs, a flexible exchange rate regime, credible monetary policy framework, healthy public and private balance sheets, and the absence of major pre-crisis asset bubbles helped contain the external shock and limit the output decline. Monetary and fiscal easing also helped cushion the economic downturn. A recovery in 2010 was largely underpinned by external demand; this recovery stalled in 2011 and is at risk in 2012 because of external risks and planned fiscal consolidation.

34. The system is relatively small by the standards of advanced economies, with commercial bank assets around 114 percent of GDP, and the ratio of credit to GDP around 57 percent. This is partly due to the fact that foreign companies generally borrow directly from banks in their home countries rather than from local banks. The banking sector is highly concentrated and dominated by foreign banks - the 5 largest banks control 70 percent of total bank assets. NBFIs are small. Unlike many other countries in the region, Czech banks are overall net external creditors.

35. The Czech financial system proved generally resilient to the effects of the global financial crisis. It is one of the few in the region where no exceptional state measures were needed. The relaxation of monetary policy via interest rate cuts and market-driven exchange rate depreciation was sufficient to cushion the cyclical downturn and support financial stability, as the banking sector has a traditional liquidity surplus. The provision of emergency liquidity by the ECB and support by their home governments benefitted some troubled parent

\footnotetext{
${ }^{14}$ The assessment was carried out by experts Mr. Goran Lind (Riksbank) and Ms. Susan Quill (Office of the Comptroller of the Currency).
} 
banks and helped shield Czech subsidiaries from induced financial distress. ${ }^{15}$ Though they were adversely affected by the weakened economy, banks continued to maintain strong capital, liquidity and profitability buffers.

\section{Preconditions for Effective Banking Supervision}

36. Legal and Judiciary System of the Czech Republic. As a member of the EU, much domestic legislation derives from EU regulations, and is frequently updated to keep pace with international standards. The CNB has the power to set, without having to obtain the consent of the government or the parliament, legally binding regulations (secondary legislation). Independence of the judiciary is established by the Constitution.

37. The Czech Accounting Standards are in substance harmonized with the International Financial Reporting Standards (IFRS), and auditing standards are in line with relevant $\mathrm{EU}$ directives on auditing.

38. The CNB owns and operates the real-time gross interbank clearing and settlement system called CERTIS. It is the only interbank payment system in the Czech Republic, and conducts all types of interbank payments in CZK.

39. The CNB may provide liquidity against collateral to a bank, a $\mathrm{CU}$ or a branch of a foreign bank, or a state-owned bank (e.g., a bridge bank). In addition, if a bank is under conservatorship, the CNB may render financial assistance to the bank to overcome any temporary shortage of liquidity.

\section{Main Findings}

While the regulatory framework and the supervisory processes are generally of high quality, a more intrusive and challenging execution of supervision would be welcome.

Supervisory authority independence, objectives, powers and resources (CP 1)

40. The CNB is the central bank and also the integrated supervisory authority regulating all financial sectors, including banks, building societies, CUs, insurance companies and investment firms. There exists a comprehensive set of laws, supported by secondary legislation (regulations) and supervisory guidelines for regulating the banking sector. The independence of the CNB is enshrined in the Constitution. The Basel Core Principles (BCP) assessors did not find any interference from external parties into the CNB's conduct of supervision. The assessors found, however, a shortage of staff resources for regulation and supervision, which made supervision less effective in several areas, such as

\footnotetext{
${ }^{15}$ The Austrian bank Erste and the Belgian KBC, each of which owns a large Czech bank, received assistance in the form of public funds during the crisis.
} 
identifying and addressing bank problems at an early stage. Finally, the CNB has entered into several MOUs, both with the MOF and with host-country supervisory authorities. The BCP assessors recommend that the domestic MOUs with the MOF are activated and are used as a transparent channel of communication between the two authorities.

\section{Licensing and structure (CPs 2-5)}

41. The CNB is the sole authority for issuing and revoking licenses for banks (including CUs and building societies). License applications are tested against a comprehensive set of requirements and criteria. The CNB checks the plans for organization, management, and business strategy as well as the financial plan. It determines that the owners and managers are fit-and-proper and that the funds to set up the bank are not compromised. In those cases where "the EU passport" is applicable, the CNB liaises with the responsible home-country authority.

42. If a person holding a qualifying interest in a bank is found unsuitable, or if the CNB's consent to his acquisition was based on false information, the CNB may prohibit the voting of his shares at a general shareholder's meeting. However, the CNB does not have the power to require the divestment of the shares.

43. For certain investments in other financial institutions, the bank must obtain prior consent from the CNB. Banks may not invest in nonfinancial assets generally, with the exception of transitory holdings such as foreclosed assets. However, there is no such requirement for investments in nonfinancial entities. Nor is there a requirement for prior notice to the CNB of intended investments. This CNB policy is intended to avoid involving itself in banks' decision-making processes. Instead, the CNB's policy is to check the appropriateness of the investment or acquisition at its next onsite visit.

\section{Prudential regulations and requirements (CPs 6-18)}

44. The Czech Republic has implemented the Basel II standard for bank capital, as set out in the relevant $\mathrm{EU}$ directives. The $\mathrm{CNB}$ cooperates, when relevant, with home country authorities, for example, on scrutinizing banks' applications for using advanced model approaches.

\section{The CNB generally applies a limit of 25 percent of a bank's capital for large} exposures to single or connected parties in the banking book, but there are important exemptions. Exposures to parent companies and affiliates within the Czech Republic which are subject to consolidated supervision by the CNB are exempted. In addition, exposures to parent companies, sister institutions, or investment firms within the EU have a limit of 100 percent of bank capital. Exposures on a bank's trading book are not included in the limit for large exposures, since they are regarded as short term, and are subject to a 600 percent limit of bank capital. The assessors acknowledge that all these exemptions from the 25 percent limit are in line with EU regulations. Nonetheless, we recommend the Czech 
authorities to apply the globally agreed $\mathrm{BCP}$, which sets a more stringent standard based on the negative experiences of concentration risks.

46. Expectations for bank risk management systems are clear and comprehensive; however, more emphasis and focus should be placed on the role and power of supervisory boards. The CNB should more formally evaluate the capability and participation of supervisory board members, through regular meetings with them and evaluation of minutes and board packages. Supervisory boards should to a greater extent than presently formally approve and monitor bank strategies and policies.

47. Trends in credit risk and problem assets, as well as market, liquidity, interest rate, and operational risks, are monitored on an ongoing basis. With the weakening Czech economy, the CNB is evaluating bank compliance with rules on restructurings and setting higher loss ratios in stress tests than warranted by experience. However, the ratio of provisions to NPLs is somewhat below the average of countries in the region and the assessors recommend targeted on-site visits to ensure that banks' provisioning and loan classification practices follow the CNB guidelines. In addition, the guidelines themselves may need to be strengthened.

48. In line with international standards, a broad range of individuals and legal persons which constitute "related parties" are defined in the Czech legislation. The regulations also require that transactions with related parties must be on market terms and on an arm's length basis. However, there are no specific regulations or requirements from the CNB requiring banks to apply specific processes and policies on related party lending. The CNB should introduce rules and guidelines for the bank's policies and processes specifically regarding related party lending since the present situation does not provide adequate protection against abuse.

49. The reliability of internal controls and internal audit are evaluated by the CNB's inspectors. If considered reliable, the CNB inspectors can leverage off of internal audit and adjust the scope of the inspection. All credit institution activities are subject to internal audit, including those that are outsourced.

50. There are gaps in the requirements for preventing banks from being used for criminal activity, including AML/CFT. Importantly, bank compliance programs and reporting requirements should broadly address financial crime as well as AML/CFT, and officers should be senior bank officials with responsibility for the institution's compliance program. AML/CFT inspections should be more frequent. Know your customer requirements related to low risk customers, beneficial ownership and bearer shares should be strengthened, and the definition for PEPs broadened. The CNB should have the ability to apply sanctions for noncompliance with AML/CFT obligations and sanctions should be reviewed to be more dissuasive. 


\section{Methods of ongoing banking supervision (CPs 19-21)}

51. Supervisory techniques applied by the CNB include off-site and on-site programs. Staffing shortfalls have created deficiencies in both programs. Full scope and targeted on-site inspections are infrequent, which is a particular concern given the need to verify that, for example, the reported high capital ratio levels are backed by a conservative approach to the identification of NPLs and the need for provisioning. Also, the CNB does not meet with audit committees and supervisory boards, unless there are exigent circumstances. Increased staffing levels are recommended to allow for more frequent on-site inspections, including for AML and for new and problem banks, and to allow for the rotation of off-site inspectors. The CNB should increase its interaction with audit committees and supervisory boards, particularly in large banks. In addition, more CNB staff is needed for regulation, not least in view of the vastly expanded international cooperation in various fora, and also for licensing and enforcement, since the mandate of the CNB supervision has been expanded to include several new sectors of financial institutions.

52. Banks submit monthly and quarterly reports to the CNB on a wide scope of activity. Weekly liquidity reports are submitted by large banks. However, there are no signatory requirements on regulatory reports. The CNB should establish such guidelines or rules, along with the possibility of imposing penalties for late or inaccurate submissions.

\section{Accounting and disclosure (CP 22)}

53. The large majority of Czech banks report in accordance with the IFRS. The local accounting standard does not differ significantly from the IFRS.

Corrective and remedial powers of supervisors (CP 23)

54. The CNB identifies problems in banks that require remedial action as part of the supervisory program, but could better match the follow up of the interventions to the seriousness of issues. Overall, the supervisory approach should move further from a reactive to a proactive stance. The CNB would benefit from introducing a structured (staged) early intervention framework which is based both on quantitative and judgmental criteria.

\section{The CNB has the necessary tools for corrective and remedial actions and the} assessors saw evidence of their use in practice. The tools include both recommendations voluntarily agreed by the bank to the CNB's formal enforcement actions for more serious deficiencies or in cases of management inaction. The assessors noted some weaknesses in the timeliness of $\mathrm{CNB}$ enforcement actions, mostly due to the internally-imposed requirement to precede such actions with a new on-site review to assess the status of the deficiency.

56. The CNB lacks the explicit power to dismiss unsuitable bank managers once they have been employed. Nevertheless, according to the Act on Banks, if the deficiencies in the banking activities are identified, the CNB is authorized to require that the bank or 
foreign bank branch implement a remedy within the stipulated deadline, which may include that that bank or foreign branch replaces the bank's managers or individuals in the management of the foreign bank branch or replaces the members of the supervisory board. While this is helpful, the assessors find that explicit powers to dismiss bank managers would be more appropriate, transparent and effective.

57. With a few exceptions, there is scant legal support to issue monetary penalties to individuals. The assessors find that the $\mathrm{CNB}$ could benefit from broader powers to set monetary penalties on individuals, as is the case in many other countries.

\section{Consolidated and cross-border banking supervision (CPs 24-25)}

58. The CNB applies consolidated supervision and is, as noted, an integrated supervisory authority. That said, consolidated supervision would become more effective if the CNB was given the general power also to directly require information (rather than to request it through the bank part of the entity), and to verify this information, through visits to nonregulated entities. Considering that the Czech banking sector is dominated by large foreign groups, this also has a cross-border dimension. The CNB works to gain insight into the consolidated cross-border group, for instance by bilateral contacts with home-country supervisors, and in multilateral contacts through the supervisory colleges and the EBA. The intensity and depth of cooperation throughout colleges have increased recently due to the fragile financial situation in Europe. In some cases, there is even weekly information sharing.

59. The CNB has an extensive network of MOUs and informal arrangements with other home and host supervisors, as well as appropriate legal powers to share information and keep information confidential, as necessary.

60. Table 5 offers, principle-by-principle, a summary of the assessment results:

Table 5. Summary Compliance with the Basel Core Principles-ROSCs

\begin{tabular}{|l|l|}
\hline Core Principle & Comments \\
\hline $\begin{array}{l}\text { 1. Objectives, independence, } \\
\text { powers, transparency, and } \\
\text { cooperation }\end{array}$ & $\begin{array}{l}\text { The CNB is the central bank and also the integrated supervisory } \\
\text { objectives } \\
\text { authority regulating all financial sectors, including banks, } \\
\text { building societies, credit unions, insurance companies, and } \\
\text { investment firms. However, while it is clear that the CNB is } \\
\text { responsible for banking supervision, there is no overarching } \\
\text { CNB mandate for prudential supervision. }\end{array}$ \\
\hline
\end{tabular}




\begin{tabular}{|c|c|}
\hline $\begin{array}{l}1.2 \text { Independence, } \\
\text { accountability and } \\
\text { transparency }\end{array}$ & $\begin{array}{l}\text { The independence of the CNB is enshrined in the Constitution. } \\
\text { However, the number of supervisory staff is inadequate. This } \\
\text { has resulted in too infrequent on-site inspections. More } \\
\text { intensive off-site monitoring and follow-up of requirements for } \\
\text { remedial action also require more staff. On the policy side, the } \\
\text { substantially increased international activity in rule-making calls } \\
\text { for more staff, not least to ensure the role of the Czech } \\
\text { authorities in the international negotiations. } \\
\text { The heads of the three supervisory departments at the CNB are } \\
\text { subject to civil service contracts. They have no fixed term of } \\
\text { office and may be dismissed on short notice without publication } \\
\text { of cause. } \\
\text { The MOF may take part in CNB Board meetings as an observer, } \\
\text { but not in meetings on operational supervisory issues. Close } \\
\text { contacts between the MOF and the CNB on regulatory and } \\
\text { supervisory issues are recommended by the BCP assessors but } \\
\text { should take place through other transparent channels. }\end{array}$ \\
\hline 1.3 Legal framework & $\begin{array}{l}\text { There exists a comprehensive set of laws, supported by } \\
\text { secondary legislation (regulations) and supervisory guidelines } \\
\text { for regulating the banking sector. }\end{array}$ \\
\hline 1.4 Legal powers & $\begin{array}{l}\text { A suitable legal framework for banking supervision is broadly in } \\
\text { place. See comment on CP } 23 \text {. }\end{array}$ \\
\hline 1.5 Legal protection & $\begin{array}{l}\text { Supervisory managers and staff are expected to be protected by } \\
\text { the collegial decision-making in supervisory matters implying } \\
\text { that the complainant primarily must sue the CNB as a legal } \\
\text { person. The present processes seem to protect staff adequately } \\
\text { for supervisory actions unless taken in bad faith. }\end{array}$ \\
\hline 1.6 Cooperation & $\begin{array}{l}\text { For cooperation between the relevant authorities in financial } \\
\text { stability and crisis management, matters have been established } \\
\text { but have not yet been activated. }\end{array}$ \\
\hline 2. Permissible activities & $\begin{array}{l}\text { There is no formal requirement in the CUA that all credit unions } \\
\text { should be listed on the CNB website. (It is now done informally). }\end{array}$ \\
\hline 3. Licensing criteria & $\begin{array}{l}\text { There is no requirement for the supervisory board to include } \\
\text { independent members, except for one member in the Audit } \\
\text { Committee. } \\
\text { Although start-ups will be monitored offsite, there is no rule for } \\
\text { the CNB to visit them at an early stage. }\end{array}$ \\
\hline $\begin{array}{l}\text { 4. Transfer of significant } \\
\text { ownership }\end{array}$ & $\begin{array}{l}\text { The CNB has the power to block the voting rights and other } \\
\text { rights of owners of qualified holdings, e.g., if the owner is } \\
\text { unsuitable. However, the CNB has no right to require the owner } \\
\text { to divest her holdings. }\end{array}$ \\
\hline 5. Major acquisitions & $\begin{array}{l}\text { There are no requirements for banks to request prior consent } \\
\text { from the CNB for significant nonfinancial acquisitions or } \\
\text { investments. } \\
\text { In the case of an investment by a Czech bank in a foreign } \\
\text { financial institution, the CNB determines that the foreign } \\
\text { supervisor practices consolidated supervision, but it does not } \\
\text { explicitly assess the quality of such supervision. }\end{array}$ \\
\hline
\end{tabular}




\begin{tabular}{|c|c|}
\hline 6. Capital adequacy & $\begin{array}{l}\text { The trigger for mandatory supervisory remedial action is } \\
\text { released when bank capital declines below two-thirds of the } \\
\text { capital requirement. This is too late, since problems may then } \\
\text { be ingrained. The law or regulations should prescribe a range of } \\
\text { remedial action to be taken, including the possible revocation of } \\
\text { the license, already when the capital ratio declines below } 8 \\
\text { percent. } \\
\text { The CNB must be provided the formal power to require banks to } \\
\text { abrogate or amend flawed internal models for the calculation of } \\
\text { risk-weighted capital. }\end{array}$ \\
\hline 7. Risk management process & $\begin{array}{l}\text { The CNB provides clear expectations and guidelines regarding } \\
\text { risk management systems. } \\
\text { More emphasis and focus should be placed on supervisory } \\
\text { boards. For example, the CNB should more formally evaluate } \\
\text { the capability and participation of supervisory board members, } \\
\text { through regular meetings with them and evaluation of minutes } \\
\text { and board packages. Supervisory boards should formally } \\
\text { approve strategies and policies to a larger extent than at } \\
\text { present. }\end{array}$ \\
\hline 8. Credit risk & $\begin{array}{l}\text { Credit institutions are required to have appropriate and suitable } \\
\text { credit risk management programs. These programs are verified.. }\end{array}$ \\
\hline $\begin{array}{l}\text { 9. Problem assets, provisions, } \\
\text { and reserves }\end{array}$ & $\begin{array}{l}\text { The past due schedule of } 360 \text { days should be shortened as it } \\
\text { applies to unsecured as well as secured loans and appears } \\
\text { excessive to the assessors. }\end{array}$ \\
\hline 10. Large exposure limits & $\begin{array}{l}\text { The definition of large exposures only encompasses exposures } \\
\text { in the banking book. Exposures in the trading book are not } \\
\text { subject to the large exposure limitations and are limited at } 600 \\
\text { percent of a bank's capital. } \\
\text { Temporary excesses over the } 25 \text { percent limit for large } \\
\text { exposures should be fully offset by additional bank capital. } \\
\text { Exposures to parent banks abroad, to sister banks or to } \\
\text { investment firms are exempted from the } 25 \text { percent limit and are } \\
\text { subject to a limit of } 100 \text { percent of bank capital. This is too high } \\
\text { and constitutes a risk to the bank. }\end{array}$ \\
\hline 11. Exposure to related parties & $\begin{array}{l}\text { There is no rule that all banks must have a separate set of } \\
\text { policies for related party transactions. } \\
\text { Define in CNB guidelines in more detail how "conflict of interest- } \\
\text { rules" should be applied for related party transactions. } \\
\text { Banks should have rules for immediate reporting to their Boards } \\
\text { of payment delays in significant related party exposures. } \\
\text { Reporting (also to the CNB) of related party exposures should } \\
\text { be separate from reporting on large exposures in general and } \\
\text { should be on an individual basis, except for insignificant } \\
\text { transactions. } \\
\text { Aggregated exposures to all related parties, excluding } \\
\text { exposures to group credit institutions and investment firms } \\
\text { under consolidated supervision, should have a limit which } \\
\text { should not exceed } 25 \text { percent of the bank's capital. }\end{array}$ \\
\hline 12. Country and transfer risks & $\begin{array}{l}\text { The requirements for country risk and transfer risk are included } \\
\text { in the requirements for credit risk management. }\end{array}$ \\
\hline
\end{tabular}




\begin{tabular}{|c|c|}
\hline 13. Market risks & $\begin{array}{l}\text { The CNB requires that banks have appropriate market risk } \\
\text { management processes. Banks must set limits, monitor activity, } \\
\text { independently value positions, and perform stress testing. The } \\
\text { CNB has the authority to limit activity, if necessary. }\end{array}$ \\
\hline 14. Liquidity risk & $\begin{array}{l}\text { Banks are required to have liquidity strategies, policies, and } \\
\text { procedures, including contingency plans, and perform stress } \\
\text { tests. }\end{array}$ \\
\hline 15. Operational risk & $\begin{array}{l}\text { The CNB provides clear expectations and guidelines regarding } \\
\text { operational risk. }\end{array}$ \\
\hline $\begin{array}{l}\text { 16. Interest rate risk in the } \\
\text { banking book }\end{array}$ & $\begin{array}{l}\text { Banks are required to have appropriate interest rate risk } \\
\text { strategies that include establishing limits, measurement and } \\
\text { monitoring systems, and stress tests. }\end{array}$ \\
\hline 17. Internal control and audit & $\begin{array}{l}\text { Banks are required to develop and maintain appropriate internal } \\
\text { audit and control systems that provide for accountability, } \\
\text { separation of the functions, safeguarding of assets, and proper } \\
\text { reconciliation processes; and appropriate independent internal } \\
\text { audit and compliance functions. }\end{array}$ \\
\hline 18. Abuse of financial services & $\begin{array}{l}\text { Compliance programs should address AML/CFT and financial } \\
\text { crime and include components for audit, training, and a } \\
\text { designated compliance officer at the management level. } \\
\text { Credit institutions should regularly report to the CNB or financial } \\
\text { intelligence unit suspected criminal activity, in addition to } \\
\text { suspected AML/CFT activity. } \\
\text { The frequency of inspections should increase. } \\
\text { The Czech Republic should increase the maximum level of fines } \\
\text { for inadequate AML/CFT programs under the money laundering } \\
\text { act. } \\
\text { Escalation procedures above the supervisor level are needed } \\
\text { for high risk accounts. } \\
\text { Know-your-customer requirements or guidelines should be } \\
\text { improved for low-risk customers and beneficial owners, and in } \\
\text { particular address bearer share companies. } \\
\text { Politically exposed persons (PEPs) should be defined to include } \\
\text { all relevant politicians (according to Financial Action Task Force } \\
\text { (FATF) definitions). }\end{array}$ \\
\hline 19. Supervisory approach & $\begin{array}{l}\text { The CNB takes a number of approaches to understand the risks } \\
\text { facing individual banks and the banking sector. }\end{array}$ \\
\hline 20. Supervisory techniques & $\begin{array}{l}\text { Full-scope and targeted on-site inspections are infrequent, and } \\
\text { the CNB does not meet with audit committees and supervisory } \\
\text { boards, unless there are exigent circumstances. Increased } \\
\text { staffing levels are recommended to allow for more frequent on- } \\
\text { site inspections, including for AML and for new and problem } \\
\text { banks, and to allow for the rotation of off-site inspectors. The } \\
\text { CNB should increase its interaction with audit committees and } \\
\text { supervisory boards, particularly in large banks. }\end{array}$ \\
\hline 21. Supervisory reporting & $\begin{array}{l}\text { The CNB should establish monthly or quarterly peer reports to } \\
\text { facilitate more frequent comparative and trend analyses. Also, } \\
\text { the CNB should establish guidelines or rules for signatories on } \\
\text { financial statement and other submissions and the capacity to } \\
\text { impose penalties on them on an individual basis. }\end{array}$ \\
\hline
\end{tabular}




\begin{tabular}{|l|l|}
\hline 22. Accounting and disclosure & $\begin{array}{l}\text { Although the CNB cannot influence the scope of the statutory } \\
\text { annual audit, it may and does in practice ask for different } \\
\text { targeted or special audits and sets the content for these. }\end{array}$ \\
\hline $\begin{array}{l}\text { 23. Corrective and remedial } \\
\text { powers of supervisors }\end{array}$ & $\begin{array}{l}\text { Introduce a structured framework for intervention in banks. } \\
\text { Introduce procedures, which in relevant cases would imply } \\
\text { narrowly targeted on-site visits to banks, to ensure timely } \\
\text { implementation of remedial requirements. } \\
\text { Broaden the powers of the CNB to apply monetary penalties } \\
\text { also on individual persons. }\end{array}$ \\
\hline 24. Consolidated supervision & $\begin{array}{l}\text { The CNB should be provided the power to physically inspect } \\
\text { entities outside the consolidated banking group. }\end{array}$ \\
\hline 25. Home-host relationships & $\begin{array}{l}\text { Although there is now Russian ownership in the Czech banking } \\
\text { sector, there is no cooperative agreement with Russia, partly } \\
\text { due to problems on the Russian side of ensuring the } \\
\text { confidentiality of information. The Czech authorities must take } \\
\text { compensatory measures to secure adequate consolidated } \\
\text { supervision. }\end{array}$ \\
\hline
\end{tabular}

\section{Recommended action plan}

61. Table 6 lists the suggested steps for improving compliance. The recommendations are listed on a prioritized basis. Recommendations are also made in cases where the ratings of the CPs were "compliant" but where the assessors identified possibilities for further improvements.

\section{Table 6. Recommended Action Plan to Improve Compliance with the Basel Core Principles}

\begin{tabular}{|l|l|}
\hline \multicolumn{1}{|c|}{$\begin{array}{c}\text { Reference } \\
\text { Principle }\end{array}$} & \multicolumn{1}{c|}{ Recommended Action } \\
\hline CP 20 & $\begin{array}{l}\text { Increase CNB staffing levels to allow for more frequent on-site inspections, } \\
\text { including for AML and for new and problem banks, and to allow for the rotation of } \\
\text { off-site inspectors. Increase CNB interaction with audit committees and } \\
\text { supervisory boards, particularly in large banks. }\end{array}$ \\
\hline $\begin{array}{l}\text { CP 23 (refers also } \\
\text { partly to CP 6 and } \\
\text { CP 20) }\end{array}$ & $\begin{array}{l}\text { Introduce a structured framework for intervention in banks. } \\
\text { Introduce procedures, which in relevant cases would imply narrowly targeted on- } \\
\text { site visits to banks, to ensure timely implementation of remedial requirements. } \\
\text { Broaden the powers of the CNB to apply monetary penalties also on individual } \\
\text { persons. } \\
\text { Set a higher capital bar (than two-thirds of capital) for mandatory supervisory } \\
\text { intervention. }\end{array}$ \\
\hline
\end{tabular}




\begin{tabular}{|c|c|}
\hline $\begin{array}{l}\text { Reference } \\
\text { Principle }\end{array}$ & Recommended Action \\
\hline CP11 & $\begin{array}{l}\text { Introduce rules that all banks must have a set of policies for related party } \\
\text { transactions. } \\
\text { Define in more detail how "conflict of interest-rules" should be applied for related } \\
\text { party transactions. } \\
\text { Banks should have rules for immediate reporting to their Boards of payment } \\
\text { delays in significant related party exposures. } \\
\text { Reporting of related party exposures should be separate from reporting on large } \\
\text { exposures in general and should be on an individual basis, except for } \\
\text { insignificant transactions. } \\
\text { Aggregated exposures to related parties, if economically or otherwise connected } \\
\text { (e.g., family), should have a limit which should not exceed } 25 \text { percent of the } \\
\text { bank's capital. }\end{array}$ \\
\hline CP5 & $\begin{array}{l}\text { Introduce explicit requirements for banks to request prior consent from the CNB } \\
\text { for significant acquisitions or investments. } \\
\text { The CNB must assess the quality of the foreign supervisor, and not only the fact } \\
\text { that it practices consolidated supervision, in the case of a Czech bank acquiring } \\
\text { (a part of) a financial institution abroad prior to giving its consent. }\end{array}$ \\
\hline CP18 & $\begin{array}{l}\text { Require credit institutions to regularly report information on significant criminal } \\
\text { activity, trends, and possible threats to reputation. } \\
\text { Increase the maximum level of fines for inadequate AML/CFT programs under } \\
\text { the money laundering act. } \\
\text { Require escalation procedures above the supervisor level for high risk accounts. } \\
\text { Improve know-your-customer requirements or guidelines for low-risk customers } \\
\text { and beneficial owners, and especially for bearer share companies. } \\
\text { Define PEPs to include all relevant politicians (according to FATF definitions). } \\
\text { Require compliance officers to be senior officers with responsibility for the credit } \\
\text { institution's financial crimes compliance program. } \\
\text { Increase the frequency of inspections. }\end{array}$ \\
\hline CP7 & $\begin{array}{l}\text { Require inspectors to evaluate the capability and participation of supervisory } \\
\text { board members, and require supervisory boards approve strategies and policies. }\end{array}$ \\
\hline CP 10 & $\begin{array}{l}\text { Exposures in the trading book should be included in "large exposures" and } \\
\text { should be subject to the overall limit of } 25 \text { percent of capital. } \\
\text { Temporary excesses over the } 25 \text { percent limit for large exposures must be fully } \\
\text { offset by adequate collateral or bank capital. } \\
\text { Exposures to parent banks abroad and to sister banks or investment firms should } \\
\text { be capped at } 25 \text { percent of the bank's capital. (The globally agreed BCPs set } \\
\text { stricter standards in these areas than the present EU legislation.) }\end{array}$ \\
\hline CP 1.2 & $\begin{array}{l}\text { Increase the number of supervisory staff in order to make possible more } \\
\text { intensified supervision, e.g., more frequent on-site visits, more intensive offsite } \\
\text { monitoring, and participation in international and domestic negotiations, e.g., on } \\
\text { new regulations. }\end{array}$ \\
\hline CP 24 & $\begin{array}{l}\text { The CNB should be given the powers to inspect entities outside the consolidated } \\
\text { banking group. }\end{array}$ \\
\hline CP 25 & $\begin{array}{l}\text { Conclude an arrangement with Russia to ensure information sharing and } \\
\text { supervisory cooperation, and also protecting confidential information. }\end{array}$ \\
\hline CP 6 & $\begin{array}{l}\text { Laws or regulations should set out a range of remedial actions to be considered, } \\
\text { including revocation of the license, when a bank's capital ratio declines below } \\
8 \text { percent. }\end{array}$ \\
\hline
\end{tabular}




\begin{tabular}{|l|l|}
\hline \multicolumn{1}{|c|}{$\begin{array}{c}\text { Reference } \\
\text { Principle }\end{array}$} & \multicolumn{1}{c|}{ Recommended Action } \\
\hline CP 4 & $\begin{array}{l}\text { Give the CNB the powers to require the divestment of a qualified holding in } \\
\text { specified circumstances, e.g., if the owner proves unsuitable. }\end{array}$ \\
\hline CP 1.6 & $\begin{array}{l}\text { The existing MOUs between the MOF and the CNB on cooperation and } \\
\text { information sharing relating to financial stability and crisis management should } \\
\text { be activated as a preparatory matter. }\end{array}$ \\
\hline
\end{tabular}

\section{Authorities' response to the assessment}

62. The CNB welcomes the assessment of the Czech regulatory and supervisory framework and acknowledges the extensive work done by the assessment team. Generally, the CNB appreciates the recognition of the resilience and stability of the Czech financial system. However, in spite of the generally positive outcome, there are some findings and recommendations that bring up concerns about the willingness and/or capability of the assessment team to consider and apply a country-specific approach, and procedural aspects of the mission.

\section{The CNB agrees that there are some minor deficiencies and gaps in the bank} regulations in the Czech Republic and accepts many of the BCP recommendations. Those could be incorporated into the legislation in a reasonable time frame. In March 2012, the $\mathrm{CNB}$ and the MOF have reactivated the existing MOU on cooperation and information sharing relating to financial stability and crisis management. The CNB accepts the following recommendations in particular:

- $\quad$ To grant the CNB the power to require divestment of a qualifying holding (Principle 4). The purpose of this principle is to prevent unwanted persons from buying into a bank. The CNB considers the existing measures to be adequate and to satisfy the desired purpose. Despite this, the CNB has already supported the idea to extend its rights and to require a person who is not trustworthy and has acquired a qualifying holding without a prior consent to get rid of its share. Such a right would greatly strengthen the position of the CNB in this area;

- To widen the framework of remedial actions (Principle 23). The CNB believes that it currently has all the necessary tools and powers to impose almost any relevant corrective and remedial measure on banks. There will certainly be further adjustments made to the supervisory tools and powers, following the adoption of the longprepared EU Crisis Management Framework, which may introduce new powers such as the widely discussed bail-ins;

- To set limits relating to exposures and further restrictions concerning intragroup exposures (Principle 10). As regards large exposure limits, the CNB follows the relevant EU Directive. Even if exposures in trading and investment portfolios are limited separately, most banks apply internal limits which normally aggregate 
exposures to the same client in the investment and the trading portfolio. All large exposure limits applied in the Czech Republic, including the intra-group limit for EU credit institutions, are fully in line with the requirements of the EU Directive. The $\mathrm{CNB}$ also takes into consideration the internal market in the EU, the existence of which implies that stricter rules for institutions located in the Czech Republic could have a negative impact on their business and profitability. Despite evidence that most EU countries are much more liberal and do not limit exposures within groups at all, the CNB accepts the recommendation to reduce exposures to members of the same group. The CNB is preparing an amendment of the Prudential Rules Decree which would tighten exposures to foreign parent and affiliate institutions from the current 100 percent to 50 percent of the capital; and

- To broaden the definition of PEPs (Principle 18). The Czech definition is fully in line with the applicable EU law. However, the CNB will consider the recommendation and the same issue will probably be discussed as part of the review of EU rules in the AML area this year.

64. The CNB is also considering incorporating the recommendation to set a higher capital bar for mandatory supervisory intervention (Principle 23).

\section{At the same time, the CNB does not share some of the $\mathrm{BCP}$ recommendations.}

The CNB is convinced that many of these recommendations go beyond European standards and regulations. As most of these standards and regulations are designed under the regime of full harmonization, there is no room for the implementation of any measures which ultimately are in violation of this full harmonization. In addition, the CNB is convinced that many of suggested recommendations are in conflict with the policy and philosophy of the current CNB's approach to bank regulation and supervision in the Czech Republic, which includes avoiding the micromanagement of banks. From the CNB's point of view, managers are primarily responsible for management. The prior consent or similar standpoint of the regulator can constitute unsubstantiated intervention, which can ultimately transfer risk to the regulator and conversely reduce managerial responsibility. In some cases, the CNB therefore considers to be fully in line with the BCPs and does not find substantive arguments for a recommendation to be made in this respect. These objections apply in particular to:

- Increase of the number of supervisory staff (Principle 1(2), 20). The CNB disagrees with the assessors' opinion regarding substantive deficiency relating to the adequacy of supervisory resources for the following reasons: i) the CNB follows the risk-based supervision approach, under which it focuses mainly on systemically relevant entities (representing the majority of the Czech banking system) and entities with high risk profiles or corporate governance deficiencies; ii) the Czech banking sector is smaller in relation to GDP than some of its Western European peers; iii) Czech banks follow a traditional banking model and their assets do not comprise substantial amounts of structured products that require time-consuming and costly 
supervision. On the liabilities side, Czech banks are primarily funded from local deposits and not from the wholesale market, which also reduces the complexity of the supervisory technique;

- Monetary fines on bank managers (Principle 23). The CNB considers the national provisions to be equivalent. Individual persons can be punished directly and indirectly, with a sufficient preventive effect. The application of monetary penalties by the CNB would only lead to a further administrative burden and responsibility of the $\mathrm{CNB}$, without any corresponding benefit to the supervisory objectives; and

- $\quad$ Additional supervision of nonregulated entities within a group (Principle 24). The CNB has reservations about enlarging the power and responsibility to inspect nonregulated entities within a group. While it may be true that there are currently no on-site inspections of nonregulated entities in a group, the CNB has this power and any suggestion to the contrary is at best misleading. The Czech regulatory framework in this area is based on the relevant EU directive; the objective of this is the supplementary supervision of regulated entities which are part of a financial conglomerate.

66. To conclude, the CNB strongly believes that it possesses sufficient operational independence, performs transparent processes and sound governance. The CNB considers itself having adequate resources to discharge its duties accountably. 